Portland State University

PDXScholar

1971

\title{
Hipólito Irigoyen's second administration: A study in administrative collapse
}

Herman John Hobi

Portland State University

Follow this and additional works at: https://pdxscholar.library.pdx.edu/open_access_etds

Part of the Diplomatic History Commons, Latin American History Commons, and the Political History Commons

Let us know how access to this document benefits you.

\section{Recommended Citation}

Hobi, Herman John, "Hipólito Irigoyen's second administration: A study in administrative collapse" (1971). Dissertations and Theses. Paper 1458.

https://doi.org/10.15760/etd.1457

This Thesis is brought to you for free and open access. It has been accepted for inclusion in Dissertations and Theses by an authorized administrator of PDXScholar. Please contact us if we can make this document more accessible: pdxscholar@pdx.edu. 


\section{AN ABSTRACT OF THE THESIS OF I.tmon John Hobi for the}

Master of Arts in History presented August 9, 1971.

Title: Hipólito Irigoyen's Second Administration:

A study in Administrative Collapse.

\section{APPROVED BY MEMBERS OF THE THESIS COMMITTEE:}

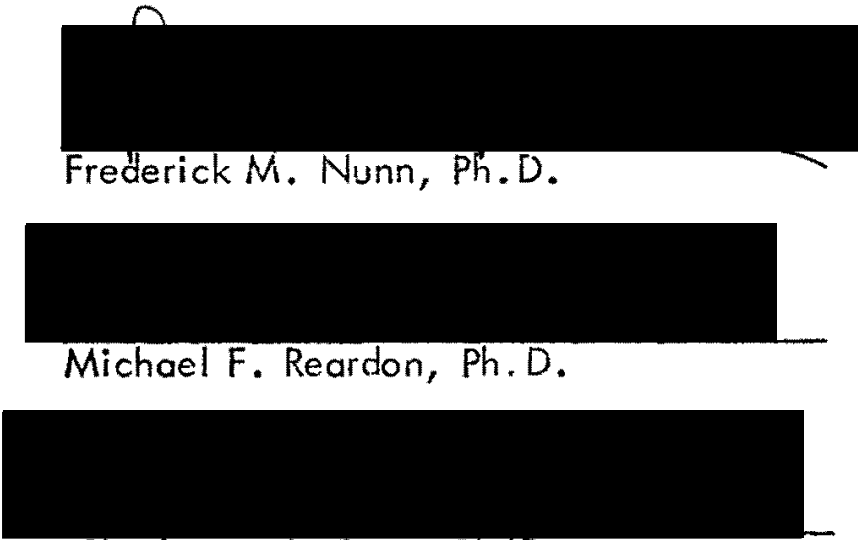

Charles A. Le Guin, Ph.D.

In 1928 Hipólito Irigoyen was the most popular President that the Argenirive people had elected. Two years later his popularity had evaporated and a few hundred military cadets ousted the government. The reasons ga beyond this rwo-year pertiod. Argentina, contrary to popular belief, did not have a democratic tradition. The nation had been ruled by the dominant economic interests up to 1916.

In 1916, Hipćlito Irigoyen was elected to his first term. The people expected him to provide them with a decent and honorable life. But in choosing the legal path of elecrions instead of revolution, Irigoyen pre-empled any revolutionary social changes. 
In 1928, Irigoyen, at 76, surprised his opponents and won a second term. He was loved by the people as he had embodied their spirit. But Irigoyen considered his victory as a mandate from the people, not an election. As the ends justified the means, the government operated on the margin of legality. Irigoyen had abandoned the principles that he had fought to maintain for over thirty years. This could have been tolerated if Irigoyen had enacted some pervasive social measures to maintain his support. Instead he permitted the usurped power to remain idle. The governmental processes slowed to a snail's pace. Appointments were not made, contracts were not signed, payments were not made while the President was intent upon increasing his power for power alone. The governmental inactivity and usurpations caused a wave of political unrest which culminated in the military golpe de estado of September 6, 1930. 
HIPOLITO IRIGOYEN'S SECOND ADMINISTRATION:

A STUDY IN ADMINISTRATIVE COLLAPSE

by

HERMAN JOHN HOBI

A thesis submitted in partial fulfillment of the requirements for the degree of

\title{
MASTER OF ARTS \\ in \\ HISTORY
}

\author{
Portland State University \\ 1971
}




\section{TO THE OFFICE OF GRADUATE STUDIES:}

The members of the Committee approve the thesis of

Herman John Hobi presented August 9, 1971.

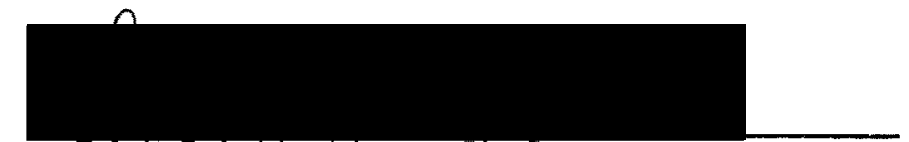

Frederick M. Nunn, Ph.D.

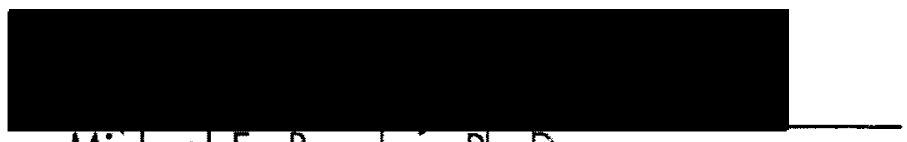

MichaelF. Reardon, Ph. D.

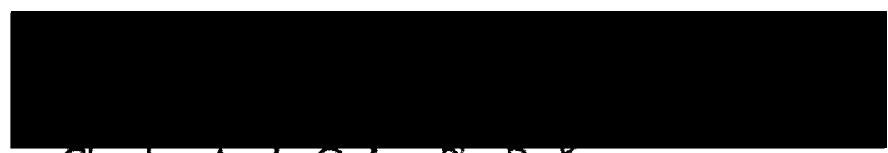

Charles A. LeGuin, Ph.D.

APPROVED:

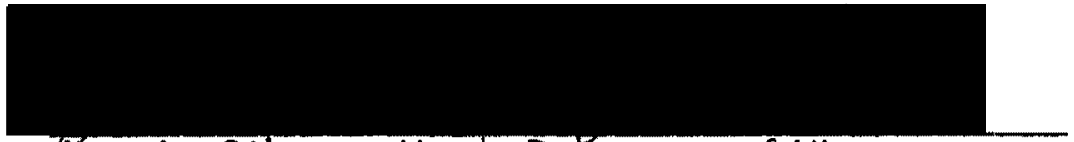

Yesse L. Gilmore, Head, Department of History

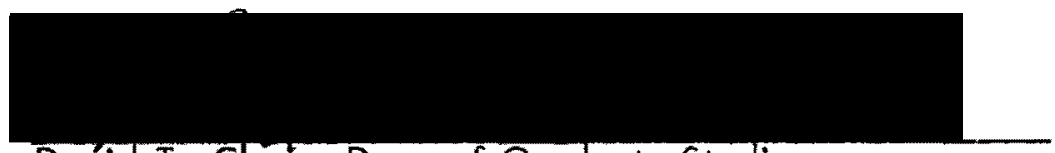

David T. Clark, Dean of Graduate Studies

August 9, 1971 


\section{PREFACE}

On April 1, 1928, after six years out of office, Hipólito Irigoyen was elected to his second term as President of the Argentine Republic with 57 per cent of the vote. He was unquestionably the most popular President that Argentina had ever elected. On inauguration day, October 12, 1928, the crowds jubilantly pulled his carriage through the streets.

The optimism of the people was unbounding. During the 1920's they had achieved unparalleled and ever increasing prosperity. Now, through their caudillo, they hoped to achieve some social justice.

But there was a shadow over Argentina. Irigoyen at 76 was no longer able to conduct a full day's work as President. As the economy declined, administrative procedures stagnated, and political turmoil increased. On September 6, 1930, General José F. Uriburu with 600 cadets from the Colegio Militar overthrew the government. In justifying his action to the relieved populace, Uriburu as provisional President proclaimed:

Answering the clamor of the people, and with the Army and Navy's patriotic support, we have assumed the government of the nation.

As the representatives of order, and having been taught to respect the law and the institutions, we have witnessed, perplexed, the unhinging that the country has suffered in recent years. 
Administrative inertia and corruption, lack of justice, anarchy in the universities, improvisation and squandering in economic and financial matters, depressing favoritism as a bureaucratic system, politics as the main occupation of the government, destructive and denigrating action in the Army and Navy, international discredit achieved through the open rejection of law, attitudes and expressions showing an aggressive disculture, exaltation of subalterns, abuse, trampling, fraud, larceny and crime, are all but a pale reflection of that which the country has had to tolerate.

When appealing to force, in order to liberate the nation of this ominous regime, we have done so inspired in a high and generous ideal. Events, on the other hand, will demonstrate that the good of the nation is the only purpose that leads us.

A golpe de estado! Rather a successful golpe. No government had been turned out of office in Argentina by the use of arms since 1862. The Argentina of 1928 was considered the most stable democracy in Latin America. How could such a viable democracy be overthrown so easily?

Unfortunately much was a facade. Popular democracy had only begun in 1914 when Sáenz Peña's electoral reform granted universal manhood sufferage. The people had not fully learned to use the ballot. The government was topheavy with an executive who dominated the Congress. For this system to function properly it was essential that the President keep the machinery of state running. It could not function by itself. And without the government running smoothly everything became disjointed. This was the crisis faced in 1930: the system had broken down.

This thesis is directed to providing an answer to the reasons for the revolution within the administration. The material is presented in three chapters. The first 
"Prelude to 1928 " provides the background to the $1928-1930$ period, with special emphasis on Hipólito Irigoyen's role. The second section "1928-September 6, 1930 " covers the factors within the administration that led to the revolution: Hipólito Irigoyen's background and philosophy of government; administrative response to the economic problems; intervention in the provinces; negation of Congress; interference in the armed forces; the opposition's reaction to inept government; and the administration's final incompetence in confronting the oncoming revolt. The third chapter interprets the material of the first two chapters. 


\section{TABLE OF CONTENTS}

PAGE

PREFACE. ................ iii

\section{CHAPTER}

I PRELUDE TO 1928............... I

II 1928 - SEPTEMBER 6, $1930 \ldots \ldots \ldots \ldots 27$

III CONCLUSION................ 89

BIBLIOGRAPHY ................... 93 


\section{CHAPTER ।}

\section{PRELUDE TO 1928}

Until 1916 an aristocracy composed of the dominant economic interests firmly controlled the political life of the nation. Argentina had an agrarian economy. Landownership was synonymous with political and economic power as well as social prestige. A comparatively small number of well-established families held the great bulk of the land, most of which was leased out under tenancy to small farmers. 1

The majority of the people had little, if any, formal education. They were dependent on the minority for employment as agrarian workers.

For the first fifty-two years of the national period the Argentine political experience was one of strong-man rule, both at the provincial and national levels. The period was one of strife and civil war. The outcome of elections was determined by a political groups's success in the control of polling places, either by intimidation of the voters or stuffing of the ballot boxes. Even after the adoption of the Federal Constitution of 1853 the situation was little better, as yoting was still not secret. 2 Due to this there was tremendous apathy in elections--a fifteen per cent turnout of eligible voters was considered high until 1916.3 
But an influx of immigrants was to challenge the aristocracy's control of politics.

Until 1853, there was little immigration to Argentina, but shortly after mid-century, a flow of Europeans began to arrive. Many of these were Italians and Spaniards, searching for new opportunities in a frontier country. 4

Most of them hoped to settle on the rich land and farm as they had done in Europe, but outside of a very few colonizing efforts, little land was available. Consequently, the majority tended to concentrate in the cities and become shopkeepers, tradesmen and small manufacturers.

The first Argentine census, that of 1869, reported 298, 854 foreigners out of a total population of $1,830,214$. By 1895 their numbers had increased to an estimated 1,500,000 out of a population of 4,000,000. 5

They proved more proficient than the natives in economic activities. More and more they controlled the import trade, ${ }^{6}$ but as few of the immigrants were citizens, they had no voice in government. They were also much disliked by wealthy Argentines, who referred to them as gringos.

The British invested more capital in Argentina than in any other area except her colonies and the United States. Naturally, Britain wished to use Argentina as a market for her own goods, and encouraged low tariffs on the part of the Argentine government.

Argentina, needing British investment, complied. Tariffs were kept low, favoring the import of British manufactured goods. 
Argentina's own local industry would have to suffer, but this was a problem which concerned neither her governing families nor the British. 7

Key positions in British enterprises were kept in foreign hands. Here, too, the new and growing Argentine middle class was excluded.

During the latter part of the nineteenth century the immigrants loomed as a new force on the Argentine political scene. Far from being politically or economically complacent, or satisfied to occupy a menial position in society, they were filled with enthusiasm for political expression and social equality. Argentina was their new home. Since most of them were of Latin stock, they assimilated well into the society, and many of them married Argentine women.

The beginning of the end for the aristocracy's absolute control of political affairs came with the administration of General Julio A. Roca in 1880. At the time the country was experiencing an unprecedented prosperity and rising inflation.

Argentine prosperity was due to the rising population in Europe and the technical developments of the refrigerator steamship and the railroad which permitted cheap transportation of beef and grain to Europe. Railroad mileage increased at an astounding rate: in 1857 the first track was laid; in 1890, 9,500 kilometers were in service; by 1914 , there were 33,500 kilometers, with an investment of 1,317 million gold pesos (the peso was on par with one dollor U.S.). Coupled with this was a 500 per cent increase of exports from 1890 to 1914.8 
The Argentine aristocracy appreciated the British investment of this period.

At a London banquet given by the financial house of Baring Brothers in 1887,

former President Julio A. Roca stated:

The Argentine Republic, which will someday be a great nation, will never forget that the present state of progress and prosperity is due, in great part, to Eriglish capital, which has no fear of distance and which has been invested there in considerable quantities in the form of railroads, streetcars, colonies, mineral exploitation, and other enterprises. ${ }^{9}$

The influx of foreign capital brought with it heavy debt-service payments.

The payments were made difficult by current unfavorable trade balances, but the inflow of capital continued unabated, resulting in increased inflation.

Inflation reached its climax during the succeeding administration of Miguel Juárez Celman. Since both Roca and Juárez were representatives of the landed pastoral interests, there was little reason for them to stop the mounting superinflation which eventually led to wide-scale business failures. The pastoral interests, wealthy from the export trade, actually profited from the runaway economy, since they received payment for their products in British pounds or French francs. The value of these latter currencies was constartly rising in relation to their own. 10

The majority of people, however, did not profit from inflation. Many were able to save during the early part of the decade, but after 1887 most of their savings were wiped out. Although salaries increased, they rose slower than prices. Merchants found import goods too expensive to buy, and many independent shopkeepers and small manufacturers, faced with bankruptcy, were absorbed by larger concerns. 
Until now the middle and lower classes had been unorganized for any political action. This experience, however, caused industrialists, small merchants, and many tenant farmers to unite. Out of the mounting resentment and grumblings over governmental extravagancies grew organization. 11

Early in 1889, over 10,000 people from all sections of the country gathered on a tennis court in Buenos Aires to air their grievances against the oligarchical government. Under the leadership of a little-known man, named Leopoldo Alem, an organization called the Unión Cívica de la Juventud (Civic Youth Union) was formed. 12 Although its followers were of diverse political beliefs, they all agreed on one thing: the regime had ruled too long in favor of a small minority, and the only way that the grievous economic situation could be improved was by giving the majority its rightful voice in government and putting the nation's democratic ideals into practice.

The Unión Cívica de la Juventud, like its successor, the Unión Cívica Radical (Radical Civic Union), made no appeals to any one group or class. It was more a mass movement without definite principles, but it was a means of expression for the inarticulate masses against the estanciero dominated aristocracy. It embraced many groups of varied interests and backgrounds. 13 Although most were immigrant tradesmen and artisans, there were some former supporters of the oligarchy, like General Bartolomé Mirre, one-time President of the Republic, and Aristóbulo del Valle. The movement was a great catchall for the dissatisfied masses, and its numbers grew not only in Buenos Ai res but throughout the provinces as well. 
The Unión Cívica de la Juventud proposed the protection of institutions and public liberties, suffrage without fraud, persecution of corrupt officials, purity of administration and to fight against the violation of provincial autonomy. 14 The program was general; as such it became a catchall for all elements.

But they were soon disappointed in the government's reaction to their program. The elections of February 9, 1890, were exceptionally violent and fradulent. 15. With the situation deteriorating, the only road open was revolution.

On July 26, 1890, the revolution began, but despite the aid received from army officers who directed it, the revolt was a failure. The rebels were defeated after several days of bitter fighting in which 1100 were killed or wounded. Although the would-be revolutionaries were discouraged they had at least won a moral victory. The government, discredited by its economic policies and the revolt, was a dead letter, 16 and in view of the preceding events, President Juárez Celman resigned in favor of the Vice President, Carlos Pellegrini.

The period from the revolt of 1890 until 1916 was filled with increasing turmoil and agitation. By 1895 one quarter of the national population was foreign born, and this element outnumbered native Argentines in every enterprise except agriculture. Also urban commercial trade was almost exclusively in its hands, 17 Coupled with the growing number of immigrants was the influx of new revolutionary ideas of social, economic, and political equality. 18 
The Unión Cívica de la Juventud was reorganized, becoming the Union Cívica Radical (U.C.R.). ${ }^{19}$ Its bases of support were the immigrants, urban merchants, clerks, and professional men, and the small landowners, especially from Santa Fe. All had been hurt by the rising inflation and the financial crisis. The leaders of the party, except Leandro Alem and Del Valle, were quite young and extremely idealistic. This youth and idealism were the hallmarks of the party for years to come. 20

Alem's nephew, Hipólito Irigoyen, ${ }^{21}$ soon became the central figure of the U.C.R. of Buenos Aires province. He came to believe that the solution to Argentine problems was quite simple--institute a system of free suffrage.$^{22}$ Because elections were not free, Irigoyen proposed the principle of abstention in elections. Coupled with this was the principle of intransigency, or unwillingness to compromise with others for immediate gains. These logically resulted in the doctrine that revolution was the only means available, under the circumstances, for gaining power. These principles were uncompromisingly adhered to by Irigoyen.

In 1893, the U.C.R. led another revolution. As Del Valle was in the cabinet of President Luis Sáenz Peña he forestalled government actions for some time. Hipólito Irigoyen installed a Radical government in La Plata. However, the holiday did not last. Federal troops routed the rebels and the conservatives returned to power. ${ }^{23}$ 
Immediately after the failure of the revolution, Alem started preparations for a new revolution, but his nephew, Irigoyen, would not support him, and without Buenos Aires province, no revolution could succeed.

Probably a successful revolution would have made Alem President. Irigoyen, apparently for this reason, withheld his support. Irigoyen felt he--and only he-could rescue the Argentine. 24 After 1893, Alem became disillusioned and on July 1, 1896, he committed suicide. Hipslito Irigoyen now led the party. Determined to remain intransigent, he nearly destroyed it.

Juan B. Justo left in 1894 to found the Partido Socialista Argentino. Lisandro de la Torre resigned in 1897 because of his conflicts with Irigoyen. De la Torre's departure was most damaging, as he was popular as well as brilliant. 25

From 1897 to 1904 the U.C.R. was dead as a national party, but Irigoyen took no heed, spending his time rebuilding the party and preparing for another revolution.

On February 4, 1905, revolts broke out simultaneously in Buenos Aires, Bahía Blanca, Santa Fe, Mendoza and Córdoba. After brief success, the revolution failed as Buenos Aires could not be secured. ${ }^{26}$

By 1905 it was clear that Irigoyen had decided he and the U.C.R. should have complete control or have nothing to do with the government. At this time the U.C.R. probably would have had a large number of congressmen and several cabinet positions had the party been under moderate leadership. 27 But Irigoyen insisted on all or nothing. He worked more on revolutionary plans to place the U.C.R. in power than on electoral reforms. 
This may be a reason for the lack of a party program. The Radicals talked of popular sovereignty and administrative morality but they did not attempt to explain their political and economic policies.

Irigoyen stated on May 13, 1905, that the revolt having failed, the U.C.R. would refurn to the passive revolution--boycotting all elections. ${ }^{28}$ Revolution, not election, was the goal of Hipólito Irigoyen and the U.C.R.

The election of Roque Sáenz Peña on April 12, 1910, was a decisive event for Argentine Radicalism. The new President was well known by many of the U.C.R. leaders, including Irigoyen. Shortly after the election, Roque Sáenz Peña met with Irigoyen. After he had offered the U.C.R. positions in the cabinet, Irigoyen replied, "Our determinarion not to participate in the government is immutable; the only thing that could change our resolution is honourable elections guaranteed by electoral reform. "29 The President was already convinced that the electoral system should be revised and he and Irigoyen held a series of conferences on the reform.

The new law provided for permanent compulsory registration at age 18 (tied to compulsory military service), and a secret, obligatory, universal male vote. 30 An added fecture was the incomplete list on which a voter could only vote for two-thirds of the candidates on his ballot for the members of the Chamber of Deputies (each party published its own ballot for the voter). Although this was supposed to ensure minority representation, it did not, as the candidate with the highest number of votes, regardless of party, was elected. One party had taken all the seats. 31 But the law was a tremendous step forward. 
However, it meant nothing if not fairly administered. The U.C.R. wanted assurances that elections would be fair and wanted to be certain that they could win before they would enter any elections. They were not disappointed on either count. Although Roque Sáenz Peña died in August of 1914, the new President, Victoriano de la Plaza, assured free elections. 32 Under these conditions, the U.C.R. entered the Presidential race for 1916. As expected, Hipslito Irigoyen was their candidate.

When Irigoyen was nominated, the U.C.R. split into two factions, both supporting him. One faction, headed by Vincente Gallo, was opposed to Irigoyen's complete dominance of the party. They wanted to make the U.C.R. a political party with a definite program. The other faction, the majority, supported Irigoyen's thought that the U.C.R. was a movement to save the nation. Since the Irigoyen faction carried the day, the U.C.R. never proposed a platform, just their regenerative ideas for the nation. 33

The Presidential election was uneventful with Irigoyen winning as expected. But out of a population of $7,704,383$ people only 15 per cent were registered to vote and only 62 per cent of these voted. Out of the total population only 9 per cent voted. Irigoyen received votes from only 4 per cent of the total population, 28 per cent of the registered voters, and 45 per cent of those who actually voted. The breakdown of the vote was as follows:

\begin{tabular}{llrrr}
\multicolumn{1}{c}{ Party } & Candidate & Votes & Electoral Votes \\
Unión Cívica Radical & Irigoyen & 339,332 & 152 \\
Partido Democráticsi-Progresista & De la Torre & 123,637 & 20 & \\
Partido Conservador & Rojas & 153,406 & 104 & 34 \\
Partido Socialista & Justo & 52,895 & 14
\end{tabular}


Irigoyen's first administration was the first freely elected government that Argentina had experienced. As such it was a step towards democratic government.

Irigoyen did express the hopes of the masses for a better life, but by choosing the ballot box instead of revolution he eliminated the possibility of revolutionary change. The conservative-dominated Congress did block many of his programs, especially in the Senate.

Irigoyen belatedly counterattacked the conservatives by intervening in the provinces, producing free elections that sent Radicals to the Chamber and eventually the Senate. Finally Irigoyen obtained some social legislation from Congress, but it was not as much as he had hoped for. In his insistent demands he was too overbearing for many of the prominent members of the U.C.R.

Irigoyen felt that his election was a popular mandate, that the people wanted him to begin the nation's regeneration. In this respect he said:

I know well that I am not a governor of the common order, because there is no power that could have persuaded me to take such a position. I am the enforcer of the supreme mandate of the people, whose duty it is to comply with the just and legitimate aspirations of the Argentine people. ${ }^{35}$

The election returns do not support Irigoyen's view. Although he could scarcely be said to have a "supreme mandate of the people," his administration was the first that was truly representative of them. Carlos lbarguren, a critic of Radicalism, wrote: 
This government of Yrigoyen was, in our history, very representative, truly representative, not because it signified an electoral majority, but because it left the destiny of the state, and that of its political springs under the domain of a vast layer of Argentine society, which up to that moment had never gravitated nor ascended to power, and which constituted one of the basic layers on which was seated the new Argentine immigration. The historian must consider that important evolution was necessary at that moment, a result of the electoral reform accomplished by President Sáenz Peña, who with his statesman's outlook saw that in these new foundations of our country there was compressed a huge reservoir of citizenry to which it was indispensable to give an outlet in civic life in order that it would not violently and rebelliously break the dike that was suffociating it. 36

When the U.C.R. agreed to enter elections in 1912 it gave up the possibility of gaining power through revolution and creating a government that could produce revolutionary changes. Instead, the U.C.R. chose to work within the system which cemented it to the previous regime.

Upon assuming the Presidency, Irigoyen was able to choose between two roads: permit the system to remain intact, leaving the Congress, where the opposition retained a majority, with its powers which would be a roadblock, or sweep away the old system illegally. In choosing the legal route, he realized he would not be able to fulfill the desires of the people. 37

The Congress, until 1918, proved a roadblock to his social legislation. What laws did pass were declared unconstitutional by a hostile Supreme Court.

The only legal tool Irigoyen possessed to subdue the opposition was intervention in the provinces.

Intervention was the constitutional device by which the federal government was permitted to temporarily assume control of the affairs of some or all of the provinces 
("temporarily" in theory; in practice some interventions lasted for years).

When a state of intervention was enacted, provincial and municipal governments in the area involved were disbanded. An appointed official with absolute power (an interventor) was sent to the province. 38

The interventor was responsible only to whoever appointed him (either the Congress or the President). He did not have to abide by provincial laws, and remained in complete control of the province until recalled by whoever appointed him. By the time the period of intervention was over, the administration party usually had control of the province. ${ }^{39}$

Irigoyen considered the governments of the conservatively dominated provinces to be illegal and immoral. They had perpetuated themselves through force and fraud at election time. 40

Irigoyen intervened in every province at least once, in five provinces twice, and in San Juan three times. These were more interventions than had been attempted by any two Presidents before him. ${ }^{41}$

Unfortunately, Irigoyen timed his interventions poorly. He should have intervened in all the provinces upon his inauguration, making a clean sweep and making his intentions clear. Instead, he did not intervene in any province until April, 1917. This partly explains the U.C.R.' 's inability to gain control of the Senate. (Another part of the explanation being that Senators served nine-year terms.) Interventions did insure free elections in the provinces. When Irigoyen was inaugurated, the U.C.R. controlled only three provinces: Entre Ríos, Córdoba, 
and Santa Fe. In 1918 the U.C.R. gained sixteen seats in the Chamber of Deputies, giving it a slight majority. By 1920 the U.C.R. secured 105 of the 158 seats in the Chamber. Irigoyen's intervention policies had been a partial success. 42

Part of Irigoyen's overall program of government for the people was to improve the standard of living among the middle and lower classes through social legislation. Shortly after inauguration he sent a series of bills which would have established a minimum wage, maximum hours and compensation insurance. Most were stopped in Congress and the few that passed were declared unconstitutional.

Some progress was made without legislation; workers' pay doubled during this period while working hours were reduced from ten to eight per day. This was due in part to the Administration's lenient attitude about most strikes. In 1921 a modified workers' code was passed.

In education, Irigoyen made great progress. Many schools were built, enrollment rose 50 per cent and illiteracy was reduced to 14 per cent by 1922 . A much needed university reform bill was passed.

A series of laws enacted needed public health programs: maternity benefits, a general sanitation bill, and extensive water purification programs. The result was a reduction of the mortality rate. 43

Irigoyen favored increased government participation in the economy. While he did want the state to assume supervision of the nation's few industries, transportation, public utilities, subsoil and land, he did not favor nationalization. 
Naturally his policies were opposed by the conservatives, but the Socialists also condemned them as too conservative. Irigoyen's philosophy came out most clearly in his action on petroleum. In 1919 an executive decree stated that petroleum was the property of the state and no longer open to private exploitation. 44

In 1922, the Yacimientos Petrolíferos Fiscales was formed, giving the government a monopoly on the production of all petroleum products.

Irigoyen also hoped for some agrarian reform. He wanted the people who worked the land to be able to own it and increase production. Congress was adamant in blocking any land reform; however, Irigoyen did open one agricultural colony project. ${ }^{45}$ Production did rise but it was due to the demand caused by the World War, not government policies.

Irigoyen's policy of neutrality during World War I, although severely criticized, brought unprecented prosperity and inflation. Unitil 1920 the nation's increasing exports were far exceeding imports. However, this was offset as Argentina was dependent upon importing most manufactured items and many processed foodsiuffs. Inflation set in due to the scarcity of these goods caused by the war. This inflation caused the bloody metallurgical strike in January of 1919 and its suppression by the police. A.lthough there was inflation the profits made from the war were used to finance Irigoyen's domestic projects. 46 The charge most often leveled against this administration was that of corruption. Irigoyen was not part of it, and he was probably blind to it even though it 
occurred in front of him. Ysabel Rennie, who admired Irigoyen, wrote:

Argentina was treated to an orgy of spoils politics in which ministers lined their own pockets and found employment for their family and friends, and in which men who were mediocre filled all the offices from school teacher to chemist... They had in their ranks few men like Thomás Le Bréton and Marcelo T. Alvear who were men of the Noventa and whom everyone respected. But the rank and file were political hangers-on and with no interest beyond their personal gain. The intransigent men, the idealists, the men of the calibre of Justo and de la Torre, had been sacrificed to Irigoyen's dictatorial leadership, and were lost for good. 47

Towards the end of his six-year term, Irigoyen made some tentative overtures to the Congressional leaders of the Radicals to see if he could persuade them to amend the Constitution in such a manner as to make him eligible for immediate reelection. 48 When nothing came of the plan, liigoyen let it be known that he wanted Marcelo T. Alvear to be President. Alvear defeated the opposition with 55 per cent of the vote. 49

During the first Radical administration the opposition had created an antiRadical front. By 1922 new circumstances pointed out the existence of fissures in the governing party, causing the opposition to adopt a new tactic: to approve of these internal divisions, directing their criticism at the abusive personalism of Irigoyen. The opposition had praised distinguished members of Congress who had shown themselves to have integrity and independence in respecting the populace, not the Radical party. 50

In continuing this policy the conservatives were able not only to indirectly control the new government, but also to displace the Radical majority in the Chamber, strengthen themselves in the provinces, and maintain their undisputed control of the 
Senate. This tactic permitted, in spite of the large majority that the Radicals obtained at the polls, paralysis of progressive legislation. In 1926, it enabled the opposition to win an absolute majority in the Chamber, to sit on the nationalization of petroleum, and to maintain their majority in the Senate until the revolution. 51

The group that the conservatives courted was the wing of the U.C.R. known as the azules (the Irigoyen faction being the rojos), who in 1916 were opposed to Irigoyen's dominance. This azul group led by Gallo, Cantillo, Le Bréton, and Melo, had wanted the U.C.R. to adopt a definite program. But they were a minority. Within the next several years they did manage to gain control of several provincial committees. In December of 1918, the azules issued a manifesto stating:

(1) Radicalism should be independent of all extraneous forces, especially personalism.

(2) Party and government separation should be absolute.

(3) The party should adopt a program in relation to the pressing political, economic, and social problems.

(4) The Radical ideal is to assure good public administration. It is the duty of the party to criticize those who do not fulfill these conditions. 52

While Irigoyen was not mentioned, it was obvious that the azul wing of the party was dissatisfied with his administration and would not contain their criticism.

Upon assuming the Presidency, Alvear made it clear that he would not be a puppet of Irigoyen. His first act was to fill his cabinet with men dissatisfied by Irigoyen's government. Of eight ministers, only one was a friend of Irigoyen. Alvear realized that if he filled his government with hipolitistas, Irigoyen, not 
Alvear would govern. Irigoyen felt betrayed. 53 The azules felt this government was a mandate for those opposed to the rojos. In the Chamber and in the provinces both factions of the U.C.R. took positions.

The first conflict came between the Vice President González (a staunch hipolitista) and senators who were opposed to Irigoyen. This rupture between the Senate and its natural President indicated the pattern of the coming crisis of Radicalism.

In December 1922, while the credentials of the alvearistas of Jujuy province were being discussed, the hipolitista faction in the Senate boycotted the session to avoid a quorum, so the minority resolved to forcefully require their presence. (The minority action was neither illegal nor unusual.) The Vice President resisted the resolution to apply force. This produced a grave incident concluding in a vote of censure of González's action. The U.C.R. Senators, Melo, Torino, Saguier, and Gallo, all azules, voted with the conservatives.

Worse, the Senate voted to resume the power to appoint internal commissions, traditionally delegated to the Vice President. Saguier proposed the measure. The U.C.R. committees of Buenos Aires, Entre Ríos, and Corrientes condemned this action. 54

The split was formalized in February 1924 when the dissident Radicals, directed by Isaias R. Amado, Mario Guido and the new Minister of Interior, Vincente Gallo, planned the intervention of Buenos Aires to oust the irigoyenista government. (lik never took place.) 
In the 1924 elections the U.C.R. elected eighty Deputies. Fifty of these maintained their allegiance to Irigoyen. The conservatives, Socialists and dissident Radicals elected Mario Guido as President of the Chamber.

The pure Radicals considered this election a product of the contubernio (concubinage). The hipolitista Deputy Dr. Andres Ferreyra complained:

We have as our President of the Republic, Dr. Alvear, who synthesized our ideas, but during our internal fights he has changed his course. But what is happening now? What is the danger? The danger that we see is that without consulting the populace, the government has decided to intrigue with the conservatives, who have been repudiated at the polls... For this I protest: because I know what has been taken from the people, that which the people legitimately gave to Radicalism... the conservatives do not have the right to direct the destiny of the nation. 55

The lines were definitive. In July 1924 the dissidents organized a party. In August they held their first meeting of the Partido Anti-Personalistas.

Most of the intellectuals, professors and lawyers of the U.C.R., as well as the old alemistas, moved over to the Anti-Personalistas. In general they were more conservative and less nationalistic than the personalistas (followers of Irigoyen). 56

In the 1926 elections the anti-Irigoyen forces triumphed. The Radical AntiPersonalistas allied with the other Radical factions in San Juan and Mendoza-the cantonistas and lencinistas-- the Partido Conservador de Buenos Aires and a number of other provincial splinter groups. The election results were: 
Party

Union Civica Radical

Anti-Personalistas and their allies

Conservative groups

Socialists
Votes

335,840

206,182

166,753

93,747
Deputies

38

20

20

$4 \quad 57$

Translated into electoral votes, no party would have received a majority.

The strong showing of the Anti-Personalistas and the conservative groups was in part due to the unprecedented prosperity that the nation was experiencing. The value of land increased at an astronomical rate, and wages went up much faster than prices, thus giving the middle and lower classes perhaps the most comfortable standard of living they had yet experienced. ${ }^{58}$

As the 1928 Presidential election approached, the Socialists proposed the intervention of Buenos Aires Province, as the U.C.R. had maintained its control. The opposition began to plan their electoral campaign around the proposed Buenos Aires intervention, as Buenos Aires' electora! votes would decide the election. 59 Alvear, however, was too honest to implement this intervention. He said to the Anti-Personalista candidate:

Melo, my friend, to intervene in Buenos Aires I would have to decide to commit a truly dictatorial act that could not be legally justified in any way. I will not do this nor will I commit any act like this even if it benefits me; much less to do this as a favor to you. I will not intervene. Go to the street and fight with your appropriate forces and win in a good manner if you can.

Irigoyen's victory was decided. 60 
The anti-Radical forces felt assured of victory. They had polled a majority in the 1926 elections. Prosperity continued. The conservatives had maintained reduced power in Córdoba, Corrientes, Salta, and San Luis. They had formed the following parties of the "right": Conservador de Buenos Aires; Liberal y Autonomista de Corrientes; Liberal de Tucumán; Unión Provincial de Salta; Liberal de Mendoza; Concentración Conservadora de Entre Ríos; Democrático de Córdoba; Liberal de San Luis; Liberal de Santiago del Estero; Concentración de Catamarca; Conservador de La Rioja. ${ }^{61}$ In order to confront the personalistas they formed a coalition with the Partido Anti-Personalista ticket of Mello-Gallo.

The opposition misjudged Irigoyen's popularity. There were even many conservatives who preferred Irigoyen to the Melo-Gallo ticket. ${ }^{62}$ Irigoyen had diligently reinforced the U.C.R. But more important, the "betrayal" of Alvear reinforced the masses' feeling that Irigoyen was their only true representative.

Although Irigoyen did not campaign, he amassed an astounding victory:

$$
\text { Candidate - Party Popular vote Electoral vote }
$$

Irigoyen - Unión Cívica Radical $\quad 838,583 \quad 245$

Melo - Frente Unico $\quad 414,026 \quad 71$

Mantienzo - Partido Socialista $\quad 64,985 \quad 3$

Others

$33,368 \quad 0^{63}$

At this time the total population of Argentina was 10, 136,738. Of this number 17 per cent were registered to vote. All totalled 14 per cent of the population voted. It was an 81 per cent turnout of the voters $(1,481,671)$, which was very 
high. Irigoyen received 57 per cent of the vote but only 8 per cent of the total population voted for him.

Irigoyen also carried a tremendous impact in the election of the Deputies. The U.C.R. won 60 of the 88 seats up for re-election. This increased their representation in the Chamber to $92 .^{64}$ Irigoyen and the U.C.R. considered the election a complete mandate from the people. 


\section{FOOTNOTES FOR CHAPTER I}

IAustin F. Macdonald, Government of the Argentine Republic (New York: Thomas Y. Crowell Company, 1942), p. 343. In the 1940's more than twothirds of the total area of Buenos Aires Province and Santa Fe were held in vast properties of over 2,500 acres by few families.

2 Macdonald, p. 85 .

3 Macdonald, p. 87.

4 John W. White, Argentina: The Life Story of a Nation (New York: The Viking Press, 1942), p. 123.

5 James R. Scobie, Argentina: A City and a Nation (New York: Oxford University Press, 1964), p. 119.

6Scobie, p. 119.

${ }^{7}$ Aldo Ferrer, The Argentine Economy, trans. Marjory M. Urquidi (Berkeley and Los Angeles: University of California Press, 1967), p. 103.

8Ernesto Tornquist \& Co., Ltd., The Economic Development of the Argentine Republic in the Last 50 Years (Buenos Aires: n.p., 1919), pp. 117-54.

${ }^{9}$ César Barros Hurtado, Hacia una democracia orgánica (Buenos Aires, 1943), p. 193, quoted in Robert Wilson Davenport, "The Revolution of 1930 in Argentina" (unpublished Master's Thesis, History Department, University of California at Berkeley, 1953), p. 9.

10Ysabel F. Rennie, The Argentine Republic (New York: The Macmillan Company, 1945), p. 178.

11 Rennie, p. 179.

12 Rernie, p. 184. 
13peter G. Snow, Argentine Radicalism: The History and Doctrine of the Radical Civic Union (lowa City: University of lowa Press, 1965), p. 12.

${ }^{14}$ Alvaro Yunque, Leandro N. Alem: El hombre de la multitud (Buenos Aires: Editorial Americana, 1953), p. 263.

15 Yunque, p. 266.

16 Gabriel del Mazo, El Radicalismo: Notas sobre su historia y doctrina (Buenos Aires: Editorial Raigal, 1955), p. 7.

17 Rennie, p. 186.

18Rennie, p. 184.

19The Unión Cívica Radical or U.C.R. was also called the Radical Party or Radicals.

${ }^{20}$ Snow, p. 14.

21 Irigoyen is the official spelling; however Hipólito spelled his name Yrigoyen. Both spellings are used.

${ }^{22}$ Snow, p. 19.

23 Rennie, p. 193.

24Manuel Galvez, Vida de Hipólito Yrigoyen: el hombre del misterio, 2d ed. (Buenos Aires: Ediciones Anaconda, 193\%), p. 105.

$25_{\text {Snow, p. }} 20$.

26 snow, p. 23.

${ }^{27}$ Snow, p. 24.

${ }^{28}$ Carlos J. Rodriguez, Irigoyen su revolución política y social (Buenos Aires: "La Facultad," 1943), p. 125.

${ }^{29}$ Snow, p. 25.

${ }^{30}$ Snow, p. 26. 
31 Macdonald, pp. 111-15. This law had produced grotesque results. In one election the party that received 27 per cent of the votes received two-thirds of the seats. Another party that received 17 per cent of the votes received onethird of the seats. Fifty-six per cent of the voters were unrepresented.

32 snow, p. 27.

${ }^{3} 3_{\text {Snow, p. } 30 .}$

${ }^{34}$ Roberto Etchepareborda, "Aspectos políticos de la crisis de 1930," Revista de Historia (No. 3, 1958), pp. 16-17.

${ }^{35}$ Ismael Bucich Escobar, Historia de los presidentes Argentinos (Buenos Aires: Roldan, 1934), p. 477.

${ }^{36}$ Carlos Ibarguren, La historia que he vivido (Buenos Aires: Ediciones Peuser, 1955), p. 316.

37Etchepareborda, "Aspectos," p. 18.

${ }^{38}$ Part I, Article 6 of the Argentine Constitution of 1853 granted intervention. Court rulings have given Congress the exclusive right to intervention when in session, Snow, p. 32.

${ }^{39}$ Macdonald, pp. 169-89, fully covers the powers of the interventor and the entire intervention procedure.

40 Etchepareborda, "Aspectos," p. 19.

${ }^{41}$ Rosendo A. Gomez, "Intervention in Argentina, 1860-1930," Inter-American Economic Affairs, 1:3 (December, 1947), p. 69.

42Etchepareborda, "Aspectos," p. 20.

43proposed and enacted sccial legislation is covered in Alfonso Diaz, El Presidente Yrigoyen y su misión histórica (Buenos Aires: Editorial Tor, 1929), Pp. 105-8 and in Silvano Santander, Yrigoyen (Buenos Aires: Editorial La Fragua S. R, L., 1965), pp. 56-72.

${ }^{44}$ Gabriel del Mazo, ed. El pensamiento escrito de Yrigoyen, 2d ed. (Buenos Aires: Edición Argentina, 1945), pp. 90-93.

45 Arturo Capdevila, "Primera presidencia de Yrigoyen," Historia Argentina contemperanea 1862-1930, Armando Braun Menendez et al. (Buenos Aires: El Ateneo, 1964), Capítulo XV, pp. 255-ó. Also see Rodolfo Puiggros, Historia de los partidos políticos Argentinos (Buenos Aires: Editorial Argumentos, 1965), pp. 143-44. 
${ }^{46}$ Escobar, pp. 470-71.

47 Rennie, p. 214.

${ }^{48}$ Galvez, p. 337.

${ }^{49}$ Escobar, pp. 495-96.

50 Manuel Goldstrai, Años y Errores (Un cuarto de siglo de política Argentina) (Buenos Aires: Editorial Sophos, 1957), p. 65.

51 Etchepareborda, "Aspectos," p. 22.

52Del Mazo, Notas, p. 33.

53 Galvez, p. 380.

54 Roberto Etchepareborda, "La segunda presidencia de Hipólito Yrigoyen," Historia Argentina contemperanea 1862-1930, Armando Braun Menendez, et al. (Buenos Aires: ET Ateneo, 1964), Capítulo XVII, pp. 350-53.

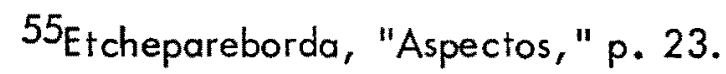

56 Snow, p. 42.

57Etchepareborda, "Aspectos," pp. 24-25.

58 Snow, p. 43.

59 Luis Alberto Romero, et al., El Radicalismo (Buenos Aires: Carlos Perez, Editor, 1968), p. 114.

${ }^{60}$ Goldstrai, p. 62.

${ }^{61}$ Etchepareborda, "Aspectos," p. 26.

62Department of State Fil es, 835.00/431, Robert Woods Bliss to the Secretary of State, March 6, 1928. (Hereafter D.S.F.)

63Etchepareborda, "Aspectos," pp. 27-28. Also see República Argentina, Ministerio del Interior, Subsecretaría de Informaciones. Las Fuerzas Armadas Restituyen el imperio de la soberania popular: Las electiones generales de 1946, Vol. I and II (Buenos Aires: Imprenta de la Cámara de Diputados, 1946), pp. 426-33.

64Etchepareborda, Historia, pp. 427-33. 


\section{CHAPTER II}

\section{8 - SEPTEMBER 6, 1930}

Hipólito Irigoyen was born on July 12 or 13,1852 . His father, a French Basque, who groomed horses, married the daughter of his patron, Alem, a member of a prominent family that was allied with the dictator Rosas. Shortly after Hipólito's birth, Rosas was overthrown and Leandro Alem, Hipólito's grandfather, was executed.

Hipólito soon learned what daily toil was. But the family was not poor. Hipólito's brothers and sisters--Roque, Martin, Amalia and Marcelina--went to school. Hipólito was guided by his uncle, Leandro Alem. He went to school, eventually entering the university to earn a law degree. Although he assumed the title of Doctor, there is no evidence that the degree was ever conferred upon him.

In 1872 his political career began: due to Alem's influence, he was appointed police commissioner of one of Buenos Aires' central parishes. He was respected in spite of his youth. In 1877 he was fraudulently elected to the Buenos Aires Province legislature. But an election scandal erupted and Irigoyen was denied the seat. In 1880 Hipolito became fully immersed in politics. President Avellaneda appointed him to the post of Administrator of Patents and Stamps, which he 
held from July to September. In September he was elected to the Chamber of Deputies where he rarely took part in debates, but when he did his word was respected, as he was always precise, concrete, and well versed. His term ended in January, 1882. 1

While still a Deputy he was named professor of philosophy and Argentine History to a women's normal school, and maintained this position until 1890. He utilized his free time working with his brother Roque, making a fortune in land and caftle, and learning philosophy, 2

He became a disciple of the German philosopher, Karl Christian Friedrich Krause (1781-1832). ${ }^{3}$ Krause, although obscure in Germany and in the English speaking world, became quite popular in Spain and in Latin America in the latter part of the nineteenth century.

The doctrine of Krause that Irigoyen adopted was eclectic, mixed with rationalism, idealism, and spiritualism. Krause tried to reconcile the idea of God, as made known to man through his faith and inner conscience, with the idea of the world, as known to man through his physical senses. He argued that God, as known intuitively through conscience, is not a personality, which embraces the universe within itself. ${ }^{4}$ The world and humanity are universal and idealistic, the world and mankind being integral parts of the universe, which is a divine organism. The process of development is through the formation of ever larger groups of people. First there is man alone, then the family, then small groups of people, nations, and then an ultimate stage where the world is one, which identifies the world with God. This development, according to Krause, 
is Right or the perfect divine law. ${ }^{5}$ Following this, Krause stated that the individual mind is part of the Universal mind; the inner self is the source of all knowledge, being in contact with God; the objective of religion is to unite oneself with God; and the ultimate goal of ethics is to do good for good's sake alone. Under these principles, self-realization will lead eventually to the realization of God. Apparently Irigoyen felt he had reached this realization. 6

Krause's philosophy is highly metaphysical and mystical and difficult to follow. This difficulty is increased, even for Germans, by the use of abstract, artificial terminology and Germanicized foreign words, which are unintelligible to those who have not studied his philosophy. Irigoyen consistently made use of this artificial, unintelligible terminology in his messages to Congress and in other State papers after he became President. He was especially fond of abstract plurals and meaningless words, which he made up himself. 7

Krause believed that God manifests Himself on the human plane through all mankind. This leads to the concept of democratic equality among men and nations, universal law and right, perpetual peace until the world is one. Irigoyen adopted this and incorporated it into his private and public life ofter 1884. He believed in absolute justice for all men and nations, and in universal peace. During his first administration this caused him to stay out of the First World War, and to withdraw from the League of Nations when Germany was not admitted. 8

In his private life, except for a weakness for women, Irigoyen was a perfect follower of Krause. He wore the somber clothes affected by Krause and his followers, never laughed, bore himself solemnly, and spoke in a high moral tone, even 
though much of what he said was not intelligible. ${ }^{9}$ Men and women, especially from the lower classes, left his presence transfixed, feeling that he was a saint. 10

During these years of philosophical studies and meditation, Irigoyen confronted that ever-pressing question, "Who am I? Why am I here? What is my mission in Life?" Irigoyen concluded that he was in direct touch with God and that God was guiding him. 11

Irigoyen maintained a frugal life in spite of his fortune. His pleasures were simple and always aesthetic. He had little faith in technical advances. He was generous in his love, especially toward the poor and humble. He gave his public salary to charity. ${ }^{12}$ Spiritualism and divination were part of his method of deriving conclusions. His memory for names, faces, all kinds of details, facts and opinions was fantastic-the never forgot a thing. He spoke not to crowds but to individuals, whom he could captivate, as he could quickly interpret their sentiments intuitively. In this Irigoyen was a master--on a personal basis he was brilliant. ${ }^{13}$

At 76 , Irigoyen was in as good health as could be expected, but many political observers felt, as proved to be true, that his gravest enemy was his age. ${ }^{14}$ By July, 1929, the United States Ambassador Robert Woods Bliss reported: "I have learned so many details of his daily doings and manner of thought that there is little doubt in my mind that Dr. Irigoyen is suffering from incipient cerebral degeneration and is gradually becoming unfit to discharge the duties of his office. "15 By October he reported that Irigoyen had suffered from bladder and heart attacks. 16 From that time until September 6, Irigoyen suffered from various ailments. The 
combination of failing health and coming senility, coupled with Irigoyen's philosophy of politics and government, made his second administration particularly inert and incompetent.

The landslide victory of 1928 had been interpreted by Irigoyen as a complete mandate or plebiscite to implement programs for the people. During his first administration he had already expressed his opinion that he was not an ordinary executive. After the 1928 election he said to a friend: "Now we are able to govern with or without the constitution. "17 Irigoyen's will had been inculcated in the multitude and proclaimed over the constitution. Unfortunately, Irigoyen had concluded (or divined) that in him was the spirit of the people and his actions were clearly for their benefit. Any opposition to Irigoyen meant opposition to the people--hence it was immoral.

By 1929 almost half of Argentina's population was concentrated in the city and province of Buenos Aires. The urban population was rising rapidly. But industrial development was not satisfactorily absorbing the available labor at decent wages. 18

The common laborer in Buenos Aires earned barely sufficient money to live on. The average family of four lived in a one-room dwelling without plumbing. Food and rent took 61 per cent of the worker's average monthly paycheck of 170 pesos. He earned so little that it was almost impossible to save. But the laborer in Buenos Aires experienced a higher standard of living than the agricultural worker. 19 Neither belonged to an effective union. Because of intense competition for jobs, labor was not effectively organized, although strikes and labor troubles were frequent. 20 
The laborers looked to Irigoyen to eliminate the inequities they were experiencing. They did not want a revolution. They wanted only a decent living and dignity. ${ }^{21}$ But to the capitalistic interests, Irigoyen's goals of political, social and economic transformation of the nation were revolutionary. ${ }^{22}$

Irigoyen wanted to narrow the cleavage between the landowner and working man as much as his power would permit. Enacting a minimum wage and projecting a law to compel large landholders to break up their holdings were the main proposals Irigoyen espoused to accomplish this leveling. ${ }^{23}$ Unfortunately, Irigoyen did not have a program for elevating the masses. He merely asked Congress to enact the measures which had been rejected during his first term.

Instead of implementing any coherent program, Irigoyen turned his attention to morality in his government. He had been shaken by the dishonesty and graft of his first term and was determined to prevent it now. Irigoyen told the Swedish Minister that he (Irigoyen) was all alone in trying to prevent corruption and he could depend upon no one in his government. ${ }^{24}$ Irigoyen became so obsessed with the idea of preventing corruption on the part of his subordinates that he attempted to examine every voucher, even though all were approved by cabinet members. As a result, the number of vouchers awaiting signatures reached almost hopeless proportions. 25 This situation was extremely grave, as the Constitution forbade the enactment of any vouchers without the President's signature. During a normal day the President would spend several hours signing vouchers--to read them would be a physical impossibility. ${ }^{26}$ Now Irigoyen's insistence upon morality in government became more damaging than the corruption and graft that had accompanied his first 
term. As a railroad executive said, "Doctrinaires of clean government are expensive to deal with. In the long run the currupt politician is better for the country because he gets things done, though sometimes the wrong ones--the honest one stalls everything." 27

The structure of Argentina's political system permitted the executive branch to dominate the legislature. Congress looked to Irigoyen to initiate legislation. But Irigoyen disliked congressional activity and ordered the U.C.R. Deputies and Senators to employ obstructional tactics. 28 Although not specifically allowed by the Constitution, the President actually decreed laws that governed the nation, without consulting Congress. Since the Presidential decrees had the substance of legislation, the President was a lawmaker on the basis of his own judgment. To placate Congress some type of legislative approval was sought. Sometimes this might take up to ten years, as was the case with the Yacimentos Petroliferos Fiscales. 29 The executive's defiance of the Constitution was also regarded as elastic. Often the congressmen who denounced executive defiance would vote for legislation prohibited by the Constitution when if was in their interests. The courts would seldom declare a law unconstitutional. 30

The executive had broad budgetany powers. If the legislature did not pass a budget for any given year, the President could adjourn Congress and decree a budget. Alvear did this in 1926 when the Congress would not approve his budget. 31 He also could authorize other expenditures without congressional approval. 32

In addition to these legislative powers, the President had wide appointive powers. Except for the federal judges, foreign ministers, certain high officers of the Army and 
Navy, and high ranking ecclesiastics, the Senate had no authority to approve his appointments. 33 The President could, and Irigoyen did, dismiss as many civil servants as he desired and hire whomever he chose in their place. It was an unqualified spoils system. 34

With such broad powers vested in the executive, it was essential that the President be well informed, but Irigoyen was isolated from the public by his ministers and other intimates. Irigoyen's personal secretary, Benevides, successfully extracted money from some Senators, Deputies, Provincial Governors, and other important politicians before he would permit them to see Irigoyen. Benevides effectively barred others, who had disturbing information, from seeing the President. 35 Irigoyen increased his isolation by not permitting his ministers to dine at any diplomat's house lest they might meet their political opponents. 36 Irigoyen had few intimates whom he consulted and generally reached decisions independently. 37

Because the presidential powers were so vast, it was essential that Irigoyen's cabinet work as a team, supplying him with the information needed to run the nation. 38 Irigoyen chose his ministers on a political basis. They were ambitious, obscure, lacking in character and intelligence, but worse, incompetent. He completely dominated them. 39 Irigoyen attempted to administer all of the insignificant details that were assigned to the ministers. It was notorious that the ministers had no authority and could not take action without Irigoyen's express approval. Irigoyen would often bypass them and give orders to undersecretaries. 40 Instead of supplying Irigoyen with information, the ministers merely carried out his wishes. 41 
Furthermore, Irigoyen's ministers realized that because of his health he would probably not finish his term. Elpidio Gonzalez (Vice President under Alvear), the Minister of Interior, and Horacio Oyhanarte, the Minister of Foreign Affairs and Worship, were competing to gain sufficient strength to step into the Presidency. By November, 1929, the fight was so bitter that neither would speak to the other. ${ }^{42}$ This infighting furthered hampered the executive's ability to conduct the affairs of state.

The lack of presidential leadership in all of these areas prompted the United States Ambassador Bliss to write:

The more I seek the cause of the discontent and unrest, the more evident it becomes that the situation is primarily the result of the inertia of the National Government, due in turn to the apparent increasing inability of the President to direct the affairs of state over which he maintains complete control. 43

Argentina withstood the crisis of 1929 with remarkable stability during Irigoyen's administration. Although the depression produced a reduction in exports, it did not cause comprehensive bank and business failures or unemployment. What financial difficulties the nation experienced were due more to the administration's nonpayment of funds than to the effects of any world-wide financial crisis.

A favorable balance of trade had existed throughout the 1920's, and was at its peak from 1926-1929:

\begin{tabular}{|c|c|c|c|c|c|}
\hline Year & $1925-26$ & $1926-27$ & $1927-28$ & $1928-29$ & $1929-30$ \\
\hline Exports & 792.50 & 960.95 & $1,048.90$ & $1,001.05$ & 661.30 \\
\hline Imports & 744.70 & 816.60 & $\$ 43.50$ & 881.70 & 773.90 \\
\hline Export surplus & 47.80 & 144.35 & 205.40 & 119.35 & -117.60 \\
\hline
\end{tabular}

Figures in millions of gold pesos. 
Foreign investment also grew during this period. Although large amounts of British capital left Argentina during the First World War, British investment rose from 1,861 to 2,140 million dollars from 1919 to 1929 . United States investment rose from 40 to 611 million dollars during the same period. 45 The United States invested more money in Argentina than in any other Latin American country except Cuba. 46

Credit was easily obtained from bonds and loans in New York, London, and in Europe. The Cédula, a bond issued exclusively in Argentine currency against the security of farm land as collaterial, became especially popular in Belgium and Holland. Circulation rose from 620 million pesos in 1920 to 1,429 million pesos in 1929.47 The government had no trouble floating loans at high rates of interest during these same years. Loans coming from New York totaled 220 million dollars between 1925 and 1928 . Their price averaged 98.5 with an average yield of 6.1 .48

Because of economic strength based on export surpluses, abundant foreign investment, and because of the ease of obtaining foreign loans, the Caja de Conversión (conversion office) was reopened in August, 1927. This was the first time it had been open since 1919. Paper money was effectively put on parity with the gold peso and was freely converted to gold. In London and New York the move was hailed as a sign of the nation's soundness and prosperity. The paper peso was backed by a gold reserve of 78 per cent and gold deposits at the Caja de Conversión increased. 49

But world prosperity did not last. By mid-1929 gold stopped coming in and began to flow out of the country. Throughout the 20 's when there were export surpluses, bank reserves increased, credit expanded and imports were stimulated. But 
in 1928-29, when exports began decreasing, imports did not. ${ }^{50}$ When foreign investments began to decline, gold began to be exported. One hundred thirty million gold pesos were exported during the last seven months of 1929.

Most of this was withdrawn from banks and did not restrict the currency, but by December it became clear that additional withdrawals would have to be taken from the Caja de Conversión, which would mean a certain constriction of currency and credit.

According to classic economics, the Caja de Conversión should have been left open and the situation would have cured itself, by drying up credit, currency and imports. It would also have meant a certain depression and widespread unemployment. Irigoyen chose to follow the unorthodox role of closing the Caja de Conversión on December 17, 1929. He stated.

Considering: that the state of insecurity in the regularity and stability of the currencies of the principal financial centers of the world adversely affect our own, giving rise to unjustified shipment abroad of gold. It is appropriate to close the Caja de Conversión. 51

In closing the Caja de Conversión, payments in gold were suspended Argentina was effectively taken off the gold standard. 52

If the peso had been kept at par with the gold currencies it would have had much more disastrous effects than Irigoyen's policy. As Harold E. Peters wrote:

That Argentina suffered so little from the world depression, in spite of the fact that the country produces those commodities whose values were most seriously affected by price, must be at least in part attributed to the behavior of the peso. 53 
The tolerably constant price level and the freedom from serious banking difficulties in spite of the almost complete lack of a system were also attributed to the suspension of the gold standard. 54

In the first half of 1930 , exports dropped and the peso declined spectacularly. 55 But the national credit did not suffer severely; Argentine bonds were still quoted in the nineties in New York. By mid-1930 the administration needed a shortterm loan to meet obligations. In April 1930 a six-month loan for 50 million dollars was obtained in New York, and in June a five million pound loan was secured in London. Both were at slightly higher prices than the last long-term loans. 56 The government also rejected several other American offers. 57

The economy's strength was reflected in government revenues. They increased from 319 million gold pesos in 1928 to 324 million in 1930 without a revision of the tax base. 58

A serious handicap of the budget was that Irigoyen did not thoroughly revise it. In fact the budget introduced in 1930 was essentially the same as the 1913 budget. During the whole period of Radical government there was never a thorough revision of the budget. 59 Also, Irigoyen did not submit the 1929 budget until January of 1930. Although such lax procedures were not uncommon, they were particularly capricious in light of the world economic crisis. 60

Before Irigoyen's inauguration business interests were quite dissatisfied. Their attitude changed when Irigoyen made his good intentions known by consulting with the leaders of the grain interests, packing houses, and railroads about their individual problems. 61 He also attempted to keep turbulent elements from dominating the unions. 62 
But businessmen's nascent confidence in Irigoyen was soon alienated by the dock strike at Rosario and delayed payments of government contracts.

The Rosario dock workers struck in July, 1929. The workers, led by Communists, demanded excessive concessions. As the strike dragged on it became increasingly damaging as Rosario was the largest grain port in Argentina. After four months Irigoyen threatened a restraining order against the workers. The Communist leaders flaunted this threat. Irigoyen was so incensed that he sent troops to break the strike. But the strike had lasted long enough to hurt exports. 63

Far more serious than any strike was Irigoyen's policy of reviewing every contract in detail before affixing his signature. The failure of the government to pay many of its important debts, both foreign and domestic, was a prime example of administrative inertia. Irigoyen had to authori ze payment for all government debts and approve all business contracts.

The Treasury had large balances from customs at mid-1929 when the government's failure to pay debts became noticeable. Irigoyen gave a reason for the government's failure to pay debts promptly when he said that he would not approve payment of debts until he was satisfied that there were no irregularities in contracts made during Alvear's administration. 64 In March 1929 an American commercial representative had an account of one-half million pesos overdue. Lack of presidential authorization, rather than lack of funds, was responsible for failure to make payments promptly. 65

Many of the contractors who held public works contracts had to suspend their work for lack of funds. This happened at the Campo de Mayo where the conscripts were sleeping on boards as barracks construction had stopped. 66 
By far the most embarrassing incident, resulting from failure to pay debts promptly, involved the delivery of two ships from English shipyards. When the Argentine crews arrived to take charge of the ships, the shipbuilders refused to turn over the vessels until payment had been made. The sailors were reduced to roaming the streets of Cowes, at the mercy of the local inhabitants as they had not been given port dues. The government also failed to meet its payrolls. From mid-1929 until the government's overthrow, payrolls were behind. 67

It is not surprising that public confidence was shaken. There was no valid excuse for Irigoyen's failure to sign contracts and his government's failure to pay its debts. Several reputable businesses were forced into bankruptcy and many others were brought to the verge of it. The United States Ambassador attributed the outflow of capital and the veering away of foreign investment to Irigoyen's failure to sign important contracts. 68 By October, 1929, the situation had reached a crisis. The bills that the government owed amounted to over 80 million gold pesos. 69 The situation improved somewhat in the coming months, but relief was sporadic and failure to pay loans continued. When Irigoyen was overthrown on September 6, 1930, 1, 159 decrees and executive orders were awaiting his signature. Five hundred twenty seven of these concerned the Ministry of Public Works, and 560 the Marine. 70

Irigoyen saved the nation considerable economic hardship in closing the Caja de Conversion. If this had been followed by sensible internal measures, confidence would have continued. Instead, Irigoyen insisted upon having a graft-free government. His policies did not end graft--rather they undermined the government's credibility. 
The arbitrary nature of Irigoyen's administration was also shown when thousands of federal civil-service employees were discharged soon after the presidential inauguration. In October, 1928, the government revealed its intention to purify the civil service of all unnecessary personnel, thereby effecting economies in the executive branch which, it was generally agreed, were long overdue. At the time there were thousands of political supporters who had campaigned for Irigoyen's re-election and it was politically expedient to create jobs for them in compensation for their services. 71

Early in January the official broom began to sweep through many federal agencies with swift and decisive strokes. The first agency affected by the reduction in personnel was the Ministry of Agriculture, which lost 3,200 employees in one day. Since its offices were left with such a small staff, it was impossible for the Ministry to carry on its normal work. It reported that even elevator service was suspended owing to lack of operators. ${ }^{72}$ Approximately one thousand employees of the State Railways were also discharged, as well as several hundred in the Post Office and Telegraph Department and numerous others in lesser agencies. Employees were released without warning or proper consideration for efficiency or seniority. ${ }^{73}$

A virtual admission of the administration's error in acting so hastily occurred shortly after the initial reorganization. In January, the Minister of the Interior, Elpidio González, promised protesting delegates of the discharged civil servants that they would be reemployed owing to the paralysis that had resulted in the agencies concerned. The following day agencies such as the Post Office and 
Telegraph Department resolved to take back many of those who had been fired. But the situation was not rectified. Later reports indicated that discharges continued, and in July 1929 several thousands of former government employees remained unemployed. 74

The mass of Irigoyen supporters were eager for government employment. They filled not only the jobs of discharged civil servants but also many unnecessary positions created for them. ${ }^{75}$ In September 1930, the Minister of Finance of the Provisional government, indicated that the employment of these partisan supporters contributed to excessive spending and the accentuation of budget deficits. He said that after Irigoyen had fired government clerks by the thousands, allegedly to reduce expenses, he then proceeded to employ three times as many as had been dismissed. 76

Irigoyen's use of his power of appointment with respect to the Consejo Nacional de Educación (National Commission of Education) was detrimental to the entire educational system. In Argentina the management of the educational system centered in the Consejo, which functioned under the auspices of the Ministry of Education. When Irigoyen took office, both the president and vice president of the five-member council resigned. Although it was Irigoyen's duty to fill these offices, he did not appoint a new president until early in 1929, and he chose to leave the other post vacant. In appointing a president, Irigoyen failed to seek the Senate's approval, violating Public Law 1440, passed in 1884. The Consejo's new president also violated this law by exceeding his powers. In an unethical fashion he personally dominated the Consejo and the district councils of education in such a way that he 
soon controlled the entire educational system. It was the first time such a thing had occurred since the law of 1884. It caused considerable alarm. 77

A principal policy of the Consejo during this period was the establishment of night schools for adult education and professional and technical schools. Progress in this field was, however, coupled with an apparent disregard for the extension and maintenance of many elementary schools. Many more elementary schools were needed in areas like Santa Fe' where the Conse jo had reported that some 80,000 children of school age had no schools to attend. ${ }^{78}$ It was increasingly evident that the country faced a serious administrative problem. These developrnents contributed to the loss of prestige suffered by the Irigoyen government.

Irigoyen also misused his appointive powers in the judiciary. His failure to appoint judges to fill vital federal judicial posts when they became vacant worked a hardship on the other judges. ${ }^{79}$ No apparent reason was given for the President's failure to appoint a total of twenty-five judges to fill vacancies, but it impeded the system, for there were not enough judges to attend to all criminal cases and delays in the settling of civil disputes resulted in all parts of the country. 80

In the field of foreign relations Irigoyen failed to maintain adequate diplomatic representation. Owing to the nature of the economy, cooperation had always been important to Argentina. Her economic prosperity depended on imports of foreign capital and labor as well as the maintenance and development of markets for exports. This was especially true in the late 1920's when nations everywhere were faced with economic difficulties and the necessity to stimulate markets. The Irigoyen administration, however, did not strengthen the diplomatic and consular corps to meet the needs of the times but instead allowed it to become ineffective. 
When Irigoyen took office the government announced its intention to reorganize the diplomatic and consular corps. The means to be used for this or the results desired were not indicated but changes occurred rapidly and with a most detrimental effect. ${ }^{81}$ As soon as Irigoyen was inaugurated, the majority of the Argentine diplomats sent congratulatory messages to the new executive as a matter of protocol. These messages remained unanswered. Then the diplomatic officials ieceived no salaries, and the government failed to answer communications, some of them of great importance. Confused by these developments, many diplomats left their posts and returned to Buenos Aires. Some attempted to see Irigoyen to reaffirm their positions, while others sought new employment. 82

Undoubtedly the most important post vacated was that of the Argentine Ambassador to the United States. Despite numerous protests Irigoyen never filled the post. The Argentine embassy in Washington, D.C. remained with only minor officials in charge, which made it ineffective for carrying out diplomatic duties at that vital post. It was noted in September, 1929, that Argentina was the only nation concerned with the proposed tariff increases in the United States that did not make a formal protest, but apparently these matters seemed of little concern to Irigoyen. 83

The recall of the Mexican Ambassador to Argentina in 1929 brought unanimous criticism from the Buenos Aires press against Irigoyen's fumbling foreign policy. The press interpreted the Mexican move as a result of Argentina's maintaining her Mexico City Embassy with only a minor official in charge for over a year, but 
most Argentine legations and consulates in Central and South American nations were staffed with minor officials who lacked the necessary rank to perform their diplomatic duties. 84

By April, 1930, there were nearly forty unemployed Argentine diplomats in Buenos Aires. Some had been there over a year. 85

Appointments to diplomatic and consular posts in Argentina were made on the basis of political influence and friendship, with no strict criterion for training or competence. The positions were often regarded as sinecures by those who held them. The appointment of Justo A. Suarez, a popular prize fighter, to the post of Chancellor at the Argentine Consulate General in New York in April, 1929, caused many disapproving Argentines to fear that their country would lose prestige as a result. Suarez had defeated all opponents in his class at home, and it was expected that he would seek fights in New York while serving in his official capacity at the Consulate. Among those who protested the appointment was an organization of students and alumni at the diplomatic and consular school at the University of Buenos Aires. In a letter to Irigoyen they stated: "Nearly all nations now appoint only career men to fill consular positions. Only among us are consuls sought at ward headquarters and in the prize ring. "86

Scarcely more than a month before the revolution, Irigoyen finally ordered all Argentine diplomatic agents at home to return to their posts under penalty of disciplinary action. The order was irregular and came too late to repair the damage that had been caused through almost two years of misdirection in diplomatic and consular affairs. 87 
President Irigoyen's use of intervention in provincial affairs was of special significance in his efforts to wrest political power from the hands of opponents and to steer provincial affairs into the hands of the personalista Radicals. He used intervention to control the four provinces in which the personalistas were a minority.

Although Irigoyen's intent was to wrest political power from his opponents, the effect of intervention was to strengthen them. For the frequency and length of interventions, together with the events which accompanied them, increased the opposition's contempt for the entire Irigoyen Administration.

The first of the interventions, occurring in the provinces of San Juan and Mendoza, were caused by institutional subversions which had developed there. Proposals for federal intervention in these provinces were introduced in Congress during the 1928 legislative session, and in Mendoza, San Juan, and the federal capital, public opinion of all but the Anti-Personalista sectors favored the proposed federal action. 88 The legislation calling for reorganization of the legislative, executive, and judicial branches of government in the provinces was approved with little opposition in the Chamber of Deputies and the Senate. ${ }^{89}$

The legis!ature of San Juan was guilty of approving tyrannical laws, the executive power had acted dictatorially, and the security of property had disappeared. Freedom of assembly and the right to express opinions had also been suppressed. 90 The causes for intervention in Mendoza were similar to those in San Juan. Carlos Washington Lencinas, national senator from Mendoza and leader of the Partido Lencinista, an Anti-Personalista Radical party, had become 
the provincial caudillo. The Governor was merely a figurehead, and the legislature was not in operation. During the recent elections, the lencinistas had committed fraud and had subsequently forced all opposition organizations to close their offices. 91

San Juan had long been the scene of stormy political affairs, which had not met with the approval of national governments. Since 1916 the brothers Federico and Aldo Cantoni had been important figures in the government of the province. They helped to maintain a spirit of lowlessness, which had characterized the province since early national days. Federico Cantoni, a former Socialist, was a supporter of Irigoyen in 1916. In the mid-twenties the Cantonis split with the U.C.R. and founded their own party. When Federico Cantoni became Governor in 1923 he followed a plan of using his power to enrich the family. 92 There were three interventions in San Juan from the time he became Governor to the congressional action in 1928, but each time the Cantonis retained their power. With the 1928 triumph in other parts of the nation, however, the personalistas in San Juan began to agitate against the Cantonis' regime, which had brought the province to a state of extreme corruption by the time of the 1928 intervention. 93 Modestino A. Pizarro, federol interventor, stated that upon arrival in the province in December, 1928, he was convinced that the solution to problems there involved much more than the reorganization of the three branches of government. He noticed a general state of fear and distrust owing to the caudillo's maintenance of a well-developed espionage system for securing information about political enemies. He also noted that the more educated had withdrawn from 
society, and a climate of immorality seemed to dominate the province. Gambling, although illegal, was very popular and openly sanctioned by the authorities for those who contributed to the official political organization. 94

Undoubtedly, the most flagrant example of government-encouraged immorality was the institution of government-agency parties. Women employees were organized into political clubs which periodically held parties for the entertainment of male government officials and other supporters of Governor Cantoni. These functions were true orgies, which the women were forced to attend under threat of losing their jobs. One of the first acts of the intervention was to isolate many women for treatment of venereal diseases and rehabilitation "to protect the public health and morality of the province." 95 Upon assuming his duties, Pizarro found the provincial treasury empty, and the economy in a depressed condition. Pizarro wrote that it was the custom in most provinces experiencing intervention for the deposed governments to leave financial matters in the best condition possible to give the interventors a favorable impression of their administrations. 96 This was not the case in San Juan, however, as he left little doubt that the cantonistas stuffed their pockeis before vacating their offices. ${ }^{97}$ They left behind them a total public debt of over twelve and one-half million pesos. The interventor acted as soon as possible to reduce expenses and to decrease the debt. 98

Although the Lencinas family had not enjoyed political control as long as the Cantoni brothers, the Lencinista Anti-Personalist Radicals had the largest single following of any political group in the province. Lencinas was able to maintain his power because the opposition Liberals and Radical Personalistas had not formed 
a united front against his authoritarianism. In the 1928 election the opposition groups received more votes collectively than Lencinas; but because they were irreconcilably disunited in the election, they were forced to accept the caudillo again as victor. 99

In Mendoza the personalista interventor, Carlos Borzani, found it especially difficult for personalistas to win in elections. This was owing not only to opposition disunity, but also to the great popularity of Lencinas among the rural people of their rural areas. 100

To the rural people Lencinas was more than a political leader. He had lived among the people for years, helping and defending them in time of trouble. He took part in their social activities and acted as godfather for an innumerable number of their children. As he had always been close to the rural populace, his strength rested in the country rather than the cities. The federal agents felt that without Lencinas his party would fall apart, since it was his own spirit and leadership that won support and strength for the organization. La Nación felt that this belief was open to question. It stated that if the party were deprived of its leader, whose popularity approached idolatry, he might well become a martyr to his many followers, complicating matters even more. 101

The intervention in the provinces of Santa Fé and Corrientes, which followed in April, 1929, resulted from presidential decree rather than from congressional law, unlike the interventions in San Juan and Mendoza. Irigoyen's decision to reorganize 
the legislative and judicial branches of the government in Santa Fe was the result of political turmoil which had plagued that province for some time. 102 Unable to cope with an uncooperative turbulent legislature and an influential Rosario caudillo, the Governor of Santa Fe, a personalista, had closed the legislature ten months earlier and was making all decisions himself. It was not surprising that an intervention should be called, since the federal government had sent repeated warnings that such would result if a republican form of government were not reestablished. It was also significant that the Rosario caudillo, who was aftempting to force his will on the Governor, was not sympathetic to Irigoyen administration.

Irigoyen decreed the intervention of Corrientes with that of Santa Fë. He stated: "The province of Corrientes exists in a state of profound disorganization owing to the arbitrariness of a government whose irregular activities make for a complete negation of the representative republican system. "103 The decree stated that the regime was maintained by fraud and oppression. It mentioned the lack of securities for free political expression and lack of safeguards for the freedom and security of the individual. It was also claimed that the legislature did not reflect the will of the electorate, and some vague remarks were made concerning irregularities in the judiciary. 104

In answer to these charges, the opposition press reported that the action was taken primarily for political reasons. In its eyes the only purpose for such a move was to dislodge a well-established political organization that opposed Irigoyen. It was pointed out that the three branches of government had operated peacefully 
and with regularity. The matter was not of such seriousness that it required an intervention, and the least the President could have done was to have waited for Congress to decide the case through congressional investigation. 105

As the winter months passed, new developments in the interventions in San Juan and Mendoza brought protests from the deposed authorities and the opposition in Buenos Aires. From Mendoza came a declaration from the Lencinista Anti-Personalist Radical party to President Irigoyen, citing numerous abuses suffered by their members at the hands of intervention authorities. They complained that they had been deprived of their freedom of assembly and that arrests without cause had become a daily occurrence. In anticipation of future elections, libretas de enrolamiento, or registration cards, had been seized from their members, thus deprivirig them of the right to vote. Complaints were also made concerning the conduct of judges, appointed by intervention authorities. It was asserfed that they were irresponsible and used their positions to damage reputations rather than to set a good example for other provincial judges. 106

It was natural to expect complaints from the displaced leaders, but charges that Modestino Pizarro was using his position and facilities to persecute them and their followers rather than to carry out his accepted functions raised new issues. 107 Also, the work to revise the government was delayed. The opposition press of Buenos Aires interpreted the delay as an intentional plan to maintain federal control in San Juan. As far as that element of the press was concerned, the interventor had confined his activities to distributing jobs to Radical Personalistas from Buenos Aires. 108 It seemed that the government was attempting to prolong the 
occupation long enough to break down the opposition's strength and to make possible the election of the Radical Personalistas at an opportune time. 109

In the past it was not uncommon for federal authorities to precipitate or maintain interventions through their own supporters in order to abolish undesirable provincial governments and to assure the establishment of governments more favorable to their own. 110 In his book, interventor Modestino Pizarro gives on indication that this might well have been the case in San Juan. 111

Maintaining the intervention until they could be sure of winning the election would benefit Irigoyen's supporters. It was also to the advantage of the Radical government to maintain its control there, since it provided employment for its partisans from Buenos Aires. In their search for explanations of the federal government's prolonged action in San Juan and Mendoza, the cantonistas and lecincistas used these reasons, among others, in their arguments that the real purposez of intervention were not being fulfilled. 112

In view of the apparent haste with which the President acted to decree interventions in Santa Fe and Corrientes before Congress opened, it was surprising that nothing had been done by August to enforce the decrees. Interventors were not sent to the provinces nor was Congress given any official report on conditions that would have prompted such a decree or its nonfulfillment. 113

In the meantime, the Governor of Corrientes, in accordance with the provincial constitution, decreed that the regular election for Governor and Vice-Governor would soon be held. It was assured that all parties would be guaranteed ample 
freedom in their election campaigns. This was affirmed by the opposition's belief that no intervention was needed in Corrientes. 114

One of the most unfortunate incidents of the interventions and the one stimulating the greatest wave of protest in 1929 was the murder of Carlos Washington Lencinas. In November, Lencinas was ordered by warrant to return from Buenos Aires to Mendoza. Despite orders from police that there were to be no public demonstrations or meetings when the caudillo arrived, an estimated five thousand persons were on hand to greet him. Lencinas, while listening to a speech, was killed by a shot fired from the crowd. Since the police in attendance were allegedly unarmed and would not interfere until a skirmish began, pandemonium broke out with considerable gun play. 115

Intervention authorities were satisfied with the explanation that the slaying was the result of a personal grudge and the assassin had been killed in the fray. The untimely death of the popular Lencinas caused a wave of protest throughout the republic. It was evident to the opposition that the real responsibility for the crime lay squarely with the federal agents who did not give Lencinas proper protection. 116 Shortly after the murder it was revealed that the caudillo sent a dispatch to Irigoyen twenty-four hours before his death in which he said, "You should adopt the means... to prevent any violence if you do not want to assume the responsibility... for the events which might occur in Mendoza upon my arrival. "117

Public opinion became so aroused that formal protests and organized meetings were staged to bring an end to the intervention. A Socialist declaration stated 
that the extension of the intervention, without any other end than the triumph of the governing party, had contributed to creating an atmosphere favorable to such manifestations of political barbarism. 118

A meeting of the conservative block of the Chamber of Deputies resulted in a resolution stating that regardless of the direct legal responsibility for the crime, the true guilt belonged entirely to Irigoyen and his agents in Mendoza. 119

As Congress was in special session, debates focused on the intervention in Mendoza. The opposition majority in the Senate ordered the interpellation of the Minister of the Interior, Elpidio González. The President of the Senate and Personalista Vice-President of the republic, Enrique Martínez, was asked to deliver the resolution. 120

In full violation of his duty, Martínez failed to communicate the resolution because he did not approve of it. In explaining his action to the Senate the following day, he made a brief reference to the gravity of such a proposal, saying that for this reason he felt it his duty not to comply with the order. ${ }^{121}$ Bitter arguments were followed by a report on the matter from the Senate Committee on Constitutional Affairs. The report stated emphatically that Martínez had erred in not carrying out the will of the Senate's majority. ${ }^{122}$ The Senate again approved the resolution, but, although it was delivered to the executive branch, there was no reply.

Faced with lack of cooperation by the personalistas' majority of the Chamber of Deputies, in obtaining an official report on conditions in San Juan and Mendoza, a group of seven Deputies of the opposition parties went to those provinces to 
investigate conditions for the benefit of the Congress. In mid-December they reported that the laws of intervention were not being carried out in the manner intended by Congress, and they indicated that the functionaries appointed to fill judicial and other posts were a major weakness of the interventions. The judges were incompetent to dispense justice, and the police appointees were persons of undesirable backgrounds who used violent methods in carrying out their work. They concluded their report with the comment that only by returning those provinces to a state of autonomy could order be restored. 123

Another significant development during the special session of the Congress was the enforcement of the President's decree of intervention for Corrientes. This occurred in late November, 1929. In the case of Corrientes, the act was in full violation of the Constitution. The Senate had refused congressional proposal for intervention, and the President was not allowed to act while the Congress was in session. 124

In the wake of the enforcement of the Santa Fe intervention, in January, 1930, came the long-awaited announcement that the elections to end the interventions in San Juan and Mendoza would be held in March.

Personalistas in these provinces affirmed that they would be sufficiently united to elect their candidates in the election, but on the whole there was little enthusiasm over the government's announcement. The opposition did not believe that the government would keep its promise and believed that the election would be delayed. 125 Months passed, conditions remained unchanged, and, as many had expected, the intervention elections were not held. In mid-June, however, the President issued a 
decree stating that the interventions in San Juan and Mendoza would end after elections were held in those provinces on September 6. This news was welcomed by the personalistas and opposition alike. For the former it meant that the personalista group in the provinces was sufficiently united to win in an election, and for the latter it meant the chance for autonomy and freedom from the oppressive interventors. 126

The enthusiasm expressed by the opposition was short lived. The Electoral Commission of San Juan ruled that women would not be permitted to vote. Although women did not vote in any other province of the republic, those of San Juan had enjoyed the privilege since 1927.

The Commission claimed that Part I, Article 8, of the Federal Constitution gave them the right to prevent women from voting: "...the citizens of each province shall enjoy all rights, privileges, and immunities inherent in the title of citizens in the others." Since women did not vote in any other province, the Commission decided that they could not vote in San Juan. (If women in San Juan could vote, women in the other provinces would not be enjoying "all rights" inherent as citizens of San Juan.) 127

Opposition in both San Juan and the federal Chamber of Deputies claimed that the Commission's action constituted an abrogation of the provincial constitution and of local laws. It was a basic violation of autonomy. It was also pointed out that the judges of the Electoral Commission were narrowly subordinated to the intervention to which they owed their appointments and by which they could be removed. 
In San Juan as well as in other provinces this affair was interpreted as proof of subversion of the Constitution. 128

Worse than the rejection of provincial laws was the increasing subversion of the Sáenz Peña law in San Juan. Confiscation of the libretas de enrolamiento continued at a greater rate after the March congressional elections than before. 129 The libretas were obtained under false pretenses and then never returned to the owners. The contention was that they had been lost or stolen. 130 According to the Federación Socialista de San Juan, some 14,000 libretas had been taken that could not be claimed for the upcoming provincial elections. ${ }^{131}$

The anticipation of elections in Mendoza was treated in a similar vein. An editorial in La Prensa stated that they were a joke and no one thought they would be honest, as nothing had been done to secure civil rights which were indispensable in a free election. 132

The climax to the developments of this two-year period came during the winter of 1930. An election for Governor and provincial legislative representatives was scheduled in the province of Entre Rios for June 1. Apparently fearing defeat, the directors of the Partido Radical Personalista in Entre Rios urged that the President decree an immediate intervention. Since Entre Rios had traditionally resisted any outside interferences and cherished its autonomy, this move aroused cons iderable adverse sentiment in the province, and the President decided in early May that it would not be undertaken, despite the fact that he had earlier agreed to oblige with an intervention. 133 
The personalistas of Entre Rios were far from satisfied with the President's decision. They had not prepared for the election, as they had expected the federal government to intervene, and when the Anti-Personalistas won a majority of the votes in the election, the personalistas began a campaign which would ultimately provoke an intervention. 134

According to Entre Rios law, it was necessary for an electoral college to be selected by the legislature to give the final decision on the electoral results before a new government could begin its work. If this formality were not observed before the end of the incumbent administration's term, the province would be without a government. The personalistas were in a position to prevent the legislature from meeting, as they controlled a majority of seats in the Senate. 135

Meeting the minority, the Senate adopted a radical means to correct the situation. On August 13, they refused the credentials of the non-cooperative Radical Personalista Senators, and the Governor decreed on December 13 that the areas from which those Senators came were to elect replacements. 136 This move raised fears that a federal intervention was soon to come, as personalista leaders in the federal capital were pressuring the President. Several days later, President Irigoyen made the dreaded announcement that intervention would soon be decreed for Entre Rios. 137

An inflamed and excited opposition held meetings and rallies of protest in Entre Rios and in other parts of the republic. President Irigoyen did not state when the intervention would take place, and there were rumors that he would 
wait to strike until conditions there had become worse so that it might mean a

full intervention. ${ }^{138}$ The Governor of Entre Rios also raised his voice in protest:

...this attempt to forcefully take over the province in which the personalistas lost in the election definitely closes the road of legality and opens that of revolution. The national government seems disposed to do anything. Besides the four thousand men of the national army who are now stationed in Entre Rios, it has been announced that even more will be sent. It is possible that in this way they will be able to discourage any threats of resistance on the part of the people, but it is certain that this will be the last victory for the Irigoyenistas. 139

Since the intervention did not occur when expected, it seemed for the moment that the majority of Entre Rios citizens had won their case. Other action precluded the need of further apprehension of intervention.

In determining the importance of the interventions as a cause of the September revolution, several factors should be considered. These incursions, in contrast to those of the previous administration, were not temporary affairs. Instead, they became permanent occupations. Irigoyen was noted for his frequent use of this power during his first administration, but the average length of those intervensions was five and one-half months. 140 Such unending control of the very provinces with governments opposed to the political slements of the national administration was interpreted by all segments of the opposition as a plan to dominate them in accord with the petty and confused interests of the Radical party.

In the realm of propaganda and interpretation, much was said of a contradictory nature on both sides of the political fence concerning the events and policies of the interventions. Regardless of what actually happened in the provinces, an active opposition made use of every opportunity it had to discredit Irigoyen and the interventors. 
In San Juan, Mendoza, Corrientes and Santa Fe there were valid reasons for intervention. There was a need for genuine regeneration to make these provinces viable democracies, but the interventions were used as a political tool. No regeneration took place nor were any of the provinces made more democratic. On the contrary the personalistas used the interventions to gain complete control of those provinces. For Irigoyen, whose dictum for so long had been free suffrage, the events that transpired made his government supercilious beyond description.

While Iri goyen's aggressive intervention policy was severely criticized, he was also attacked for his distaste for congressional activity. He attached little importance to Congress, as his electoral mandate proved that he was the true representative of the people. Also the Congress slowed measures down because of their incessant debating and arguing. As the U.C.R. was under Irigoyen's control, he was able to command them as he saw fit. His overall policy was to obstruct congressional acticity and rule by decree.

Irigoyen's attitude was not completely unjustified as the Congress endlessly held up legislation by debating the most trivial issues. The Senate was the main roadblock. When Irigoyen was inaugurated there were 58 treaties and conventions awaiting ratification by the Senate that had been pigeonholed for several years. ${ }^{141}$ Since the U.C.R. only held 7 seats, while the opposition parties held 19, they were at the mercy of the majority, ${ }^{142}$ and the majority in the Senate, while able to pass or reject legislation from the lower house, was not receptive to Irigoyen's proposals. 
The first congressional session of Irigoyen's second administration was scheduled to commence on May 1, 1929. Congress finally met on May 24. This was not unusual as in the past 73 sessions Congress had only met four times on its mandatory opening day of May $1 .{ }^{143}$ When Congress convened, Irigoyen did not present a program for legislation, and he further broke tradition by sending the Minister of Interior, Elpidio González, to read his opening message instead of presenting it himself. The message stated: "The executive has not had sufficient time to set forth in detail all its intentions regarding the well being of the nation...." In the meantime Congress was requested to dedicate itself to the many bills rejected during the years 1916-1922. Obviously this was insulting to Congress. But Irigoyen did not want to share his power. 144

As the Congress had come to depend upon the executive for initiation of legislation, the 1929 session was particularly unproductive. Also the Congress regressed to frequent debating. The Senate debated for almost two months on the credentials of the Senators-elect, Carlos Washington Lencinas, Federico Cantoni, and Carlos Porto, and their credentials were finally rejected. ${ }^{145}$ Only three laws of any importance were passed: Law 11,544 establishing maximum hours of work for laborers; Law 11,563 ordering a census of the national income; Law 11,570 applying fixed standards for the application of work laws. Of these laws the first two had been introduced during Irigoyen's first term. ${ }^{146}$

Because so little had been proposed or accomplished during the regular session, Irigoyen, now apparently willing to share his mandate, decreed a special session to commence on October 7, 1929, to deal with the following: the budget, a law 
governing the issue of mortgage bonds, the nationalization of petroleum, establishment of a national farmers' bank, establishment of fixed agricultural rents, bonds for paving the streets of Buenos Aires, a highway bill, a public works bill, ratification of appointments made by the government, and a bank employees' holiday and pension bill. 147

As in the regular session, politics was an obsession in the special session. The Senate minority found it necessary to impose a fine to obtain a quorum by November 19, and the Chamber of Deputies did not meet until December. The 1929 budget and Law 11,575 establishing bank employees' pensions and holidays were the only measures passed during the entire session. However, the Chamber of Deputies did pass most of Irigoyen's proposals but the Senate blocked them. 148 Irigoyen, naturally incensed, stated in January of 1930: "If you (Congress) do not like my legislation then enact that which is better, but do not go to the nation without assurances and guarantees of appropriate legislation. "149 As the session was almost over it was pointless to ask Congress to initiate any legislation, let alone pass what it had initiated.

But Irigoyen had other reasons for disliking the congressional, and especially senatorial, activity. The Senate had insisted upon its right to review executive acts and interpellate ministers. Irigoyen denied that the Senate had that right. But the Senate challenged Irigoyen's view before the Supreme Court. In upholding the Senate's right to review legislation, the Supreme Court stated: "The legislative branch is the depository of the greatest amount of power and is... the immediate representative of sovereignty. "150 
Irigoyen put special emphasis on the March 1930 elections for Deputies. The U.C.R. was determined to gain as many seats as possible by whatever means necessary. Unfortunately the U.C.R. committed many fraudulent acts in securing this election. 151 But they were successful in winning 59 of the 90 seats up for election.

The election was not a genuine victory for the U.C.R., as the fraudulent procedures caused so much resentment among some party members that they began criticizing Irigoyen's policies. They let it be known that they did not approve of many of the U.C.R.'s candidates or of the violence displayed by their fellow party members in the elections. ${ }^{152}$ Although all members of the U.C.R. were opposed to the Anti-Personalistas and the conservatives, they divided over purity in elections and the importance of Congress. Irigoyen was able to keep a majority of the U.C.R. in line. Elections were to be won at all costs and Congress was to be impotent. 153 But this fissure, which had developed inside the ruling party, pointed to the growing dissatisfaction of Irigoyen's policies and complete dominance of the party.

Although the U.C.R. was victorious at the polls, Irigoyen had apparently decided, because of his inability to coerce Congress to pass all of his legislation in the 1929 regular and special sessions, to employ obstructional tactics so Congress could not convene. In doing this he could rule by decree without dissident personalista Deputies or inquisitive Senators. 154

When the 1930 congressional preliminary sessions began, the U.C.R. used debating over Deputies' credentials as a means to neutralize Congress. As the 
U.C.R. controlled the Credentials Committee they accepted all of their Deputyelects, but rejected four of the opposition's Deputy-elects. But worse, they would not permit the Chamber to form a quorum. The debates ran on until September 1, when a quorum was held and the Chamber convened, but it was too late. 155 The opposition was partly guilty, as they permitted the debates to lapse into trivia. One day was wasted arguing over staying on the subject. 156 The Senate, while controlled by the opposition, was as impotent as the Chamber. One day the Senate debated the validity of a man's signature. ${ }^{157}$ The Senate only held one preliminary session on April I until the revolution. La Prensa was continually criticizing the Congress through August for its nebulous debates, which were especially damaging in light of the presidential usurpations. 158

Irigoyen preferred to rule by decree than wait for congressional action. His most important decrees in 1928 and 1929 were: organizing sanitary controls to insure the quality of cereal exports, reduction of export tariffs in Rosario, extending and improving the railroad networks, construction of a new building for the medical school, creation of the Instituto de Petroleo, prohibition of iron exports, construction of 1700 schools, intervention with troops and settlement of the strikes in Rosario and Santa Fe. Irigoyen's decrees in 1930 were: creation of the Institute of Nutrition, subsidizing the Institute of Cancer, imposing a uniform price on gasoline throughout the nation, and decreeing May lst as Labor Day. 159

It was abvious that Irigoyen did not have a plan to raise the standards of the workers. He left those bills to the Congress, which he had effectively paralyzed. And in 1930 Irigoyen did not decree anything of importance. 
Although Irigoyen was free to do what he chose, it became apparent that he did not have a program or plan to guide him, save distributing the spoils of office and eliminating his opposition. During 1930, the government decreed so little and became so vacillating and inept that there was no effective leadership in the nation. Congress had been effectively checked but not replaced. With this leadership void, the nation floundered. A solution had to be found.

The Army ultimately provided the solution to Irigoyen's continued misuse of power. The President had caused resentment among the officer corps because of his irregular and disruptive policies. While irregular promotions caused widespread resentment, Irigoyen also failed to maintain expenditures for military equipment. As the time passed, dissatisfaction increased among the military. By August 1930 certain segments of the officer corps were ready to use force to oust Irigoyen.

Irigoyen viewed the military as a large group or political unit rather than a hierarchial institution where morale and discipline are closely interrelated in a 160

set pattern. Because of this, he freely dispensed promotions as political favors to officers, regardless of their standing for promotion. Any officer who could arrange an interview with the President was virtually assured of a promotion. 161 Other forms of political favoritism included: retroactive promotion of retired officers with retroactive pay (which was contrary to specific provisions of military law); reincorpcration of long since discharged officers with full credit for serving the intervening years; and alternation of the date of the date-of-enlistment of favored active-duty officers, giving them seniority over their contemporaries, and an advantage for promotion. 162 
As disturbing as these political favors, was Irigoyen's lack of promotions of the superior grades and delaying promotions in the field and junior grades of the military. The organic military statute called for promotions to be made effective every December 31, and lists were customarily issued around that date. The promotions of the superior officers (colonels and generals) required the Senate's approval, which was usually given without difficulty. But Irigoyen did not submit any names to the Senate in 1929 , and since the Senate did not sit in 1930 , there were no promotions made during the entire administration. This was serious, as the officers who were to be advanced were frustrated in not being able to make the magic change from field to superior grade officers. ${ }^{163}$ And these officers, lieutenant colonels, who were not promoted, held the regimental command posts. Irigoyen delayed approval of the field and junior grade promotions, which annoyed many officers. The 1928 list was issued in the following May, and the 1929 list was not issued until after the March elections. 164

Irigoyen reduced military armaments spending from more than 16 million pesos annually to 137,000 pesos annually, which helped to widen the cleavage between segments of the officer corps and the administration. 165 In addition to this, there was not a single new armaments contract approved. Those pending were held up because of Irigoyen's refusal to sign contracts. This practically shut down the airplane factory in Córdoba and halted the delivery of the two British destroyers. 166

But Irigoyen placed more emphasis upon individuals than upon institutional strength, more on men than hardware. A general pay raise was enacted as well as steps to raise pensions to the level of active pay. Government outlays for 
pensions rose from 21.6 million pesos in 1928 to 36.1 million in 1929. Manpower also increased as conscription was raised from 24,838 men in 1929 to 25,098 in 1930. The enrollment of cadets at the Colegio Militar (Military Academy) raised from 542 in 1928 to 628 in 1930.167

Although Irigoyen increased manpower and raised the armed forces' pay, his interference in promotions and cutbacks in armaments spending caused growing dissatisfaction among the military. Increasing numbers of officers came to believe that Irigoyen was irreparably damaging the institution and that he did not understand the nation's defense needs. 168 As lirgoyen's administration continued its interference in the organic processes of the Army and Navy, the opposition grew. It became increasingly evident to those officers opposed to Irigoyen that the situation would have to change.

The armed forces were sharply divided at the time of Irigoyen's inauguration. One faction, which had formed the illegal Logia General San Martín in 1921, was opposed to mixing politics in the armed forces. While Augustín P. Justo was War Minister under Alvear, the Logia was able to gain his support. Officers who were politically minded were blacklisted by the Logia and received undesirable assignments. By 1926 the Logia was disbanded, as its members felt that they had accomplished their goals. 169

With Irigoyen's return in 1928 the blacklisted officers gained control of the War Ministry. Now officers who had been identified with the Logia were relieved of their posts and placed in unassigned status. Eventually many of these officers were given assignments but others preferred to retire. ${ }^{170}$ This group of retired 
and unassigned officers, headed by General José F. Uriburu, were to organize and form the conspiracy which led the revolution of September 6, 1930.

Opposition to Irigoyen's administration began building in the winter of 1929, when the arbitrary nature of the government became apparent. Non-signing of vouchers, arbitrary dismissal of public employees, intervention in San Juan, Mendoza, Corrientes, and Santa Fe, degredation and paralysis of Congress, and interference in the armed forces provided ample fuel for the opposition's attacks on Irigoyen's administration.

Opposition centered in political action groups, such as the ten-year-old right-wing Liga Patriótica Argentina and the similar but more militant Liga Republicana which had been formed to oppose Irigoyen. By October 1929 the Liga Patriótica was conducting vociferous anti-administration street meetings. Irigoyen's health was affected by these meetings to the point that the Minister of Foreign Affairs, Horacio B. Oyhanarte, personally requested the leader of the Liga Patriótica to prevent a demonstration. ${ }^{171}$

While Irigoyen was intent in intervening in the provinces and interfering in elections in those provinces, he never attempted to muzzle the press or intimidate the opposition. While he had the power to call a state of seige, he never did. In general he respected the opposition's right to free speech and free press. 172 The opposition press was capably led by La Prensa and La Nación, the two most prominent newspapers in Argentina. They were continually criticizing Irigoyen's every move and they left no quarter. When Carlos Washington Lencinas was assassinated in November of 1929 their campaign against the government 
began and did not stop until Irigoyen's ouster. 173 The irregularities in the interventions were continually brought out and Irigoyen was blamed for everything from university disorders to labor disputes. ${ }^{174}$ Although the press was unfairly critical at times, the iniquities of the government became obvious.

The campaign for the March 1930 election of Deputies was extremely heated. The opposition cried: "The specter of dictatorship is starting to fall upon us. "175 The confiscation of libretas in San Juan was used to confirm the accusation. Just as serious was the violence perpetrated by the U.C.R. in their campaign. In Lincoln, a small town in Buenos Aires Province, while the opposition was conducting a rally, members of the U.C.R. began shooting into the crowd from rooftops and automobiles. Two people were killed and several wounded in the ensuing battle. But that was not the only gunplay, as the members of the U.C.R. were found shooting at the opposition in Toledo, Olmas, Godoy Cruz and in Buenos Aires. Because of their election activities and lrigoyen's failure to satisfy the electorate, the U.C.R. lost its mandate. The election results reduced their share of the vote to 48 per cent. 176

While the votes were being counted, news of electoral scandals broke. The worst took place in Córdoba where members of the U.C.R. stole ballot boxes from a counting place and kidnapped the officials who were to count the ballots. Even if the people were freely allowed to vote for whomever they chose, this action negated the purpose of an election. 177

On the eve of the elections the high officials of the U.C.R. had been as sure of victory as Irigoyen. They were completely shocked when they had lost their 
majority in Buenos Aires, which they had maintained for the past 14 years. 178 Apparently the loss of votes in this election was one of the reasons for Irigoyen's inactivity.

There had been an assussination attempt in December 1929 which prompted Irigoyen to keep an excessive number of armed guards, which was one of the reasons for his increased isolation. 179 On election day in March 1930 he stationed wellarmed troops around his residence in fear of violence from the opposition. When he rode in the presidential limousine he kept the curtains drawn and always had a motorcycle guard, but this protection turned into isolation from reality. Irigoyen's friends convinced him to disregard the opposition press while they assured him that he was taking the correct actions. Those who wanted him to end the misgovernment were called traitors or dismissed as crazy by other intimate friends of the President. 180 The March 1930 elections shocked Irigoyen and he apparently did not understand the cause of his party's defeat. He could not cope with his loss of popularity. Irigoyen's reaction to the election setbacks was manifested in his refusal to carry on the many daily functions of his office. This inactivity lasted from March until August, when Irigoyen filled several vacancies in the judiciary, authorized promotions in the armed forces, and authorized payment of some public works projects in the provinces. 181 But the action was not sufficient to meet the coming crisis.

Irigoyen had governed too long on the margin of legality. The most obvious product of his administration was an increase in political turmoil and corruption of the democratic procedures. ${ }^{182}$ A by-product of his misgovernment was the unification of the opposition. Forty-four Deputies from the Independent Socialists, 
Anti-Personalistas, liberal and conservative parties issued a manifesto, on August 9, that called for: coordinated action in both chambers to force the President into complying with the Constitution, reopening the Caja de Conversion, and loyally applying the basic organic laws. They promised to defend the people against the illegal presidential acts and to create "... a civic spirit to resist these abuses and take off the fetters. "183 The opposition had begun its final campaign against Irigoyen. The Anti-Personalista and conservative Senators met on August 20 and signed a manifesto similar to that of the Deputies. 184 Soon prominent people were asking for Irigoyen's resignation while hinting that if it did not come a revolution was certain. 185 The 44 Deputies met again on August 22 to renew their demands for reform. The Liga Patriótica and the Liga Republicana increased their activities. 186 General Uriburu was coetanously building support in the Army to insure a conspiratorial victory by the use of force.

Although General Uriburu headed the revolutionary movement there were several factions within the armed forces that were planning a revolt. Uriburu successfully united these factions under his leadership during the first week of September 1930. 187 His original plan had called for a thorough revision of the entire governmental system based on the carporativist idea. 188 But the other major faction headed by former War Minister Justo wanted to adhere as closely as possible to the Constitution. 189 This difference of opinion caused numerous delays in planning as the two factions could not unite. Both factions wanted to oust Irigoyen but they could not achieve their ends until they agreed upon unified goals for the revolt. This meant that the revolutionary effort was indefinite until this unification could be achieved. 
During the last weeks of August everybody was talking about revolution, and everyone believed that it was coming, except Irigoyen, who could not conceive how anyone could make a revolution against him, the mandatory of the Argentine electorate. Apparently his senility had become complete. ${ }^{190} \mathrm{He}$ did not want to believe the news of revolutionary activities, and because of his senile sentimentalism was reluctant to take forceful measures. 191 When he was told of the revolutionary activities he invariably replied: "Nothing will happen; they are just momentary political agitations, a consequence of the last electoral conflicts. They will soon vanish."192

Irigoyen's reluctance to act was particularly frustrating to his War Minister, General Luis J. Dellepiane. Since early August he was well informed about General Uriburu's revolutionary activities through loyal officers who had infiltrated meetings. The information was transmitted to Elpidio González, who received it with indifference. On August 22 Dellepiane had received further information that convinced him of the impending revolution. He sought Irigoyen's approval for quick action but was met with indifference, even ridicule, by González, Juan de la Campa, the Minister of Justice, and the chief of police of Buenos Aires, Juan J. Graneros, who ironically attributed Dellepiane's anxiety to a nervous affliction. 193

Graneros had other reasons for discrediting Dellepiane. A conspiracy had developed within Irigoyen's Cabinet, headed by the Vice President, Enrique Martínez, Elpidio González, Juan de la Campa and Juan Graneros. Aware of Irigoyen's physical and mental unfitness, they considered his resignation inevitable. 
Worried by the administration's rapid loss of popularity, they viewed Irigoyen's resignation as a necessity to restore popularity. So the conspirators worked to step into the presidency to save the U.C.R.'s predominance and their personal privileged positions. 194

Uriburu exploited this internal struggle by assuring Enrique Martínez that the sole purpose of the revolution was to force out Irigoyen in order to place Martínez in the presidency as the constitutional successor. 195 This is why he and the others discredited Dellepiane's attempts to stop the military conspiracy and to persuade Irigoyen that rumors about a revolution were false. Irigoyen's naivete made their plans easier and was only matched by their own naivete in believing that the military uprising would be made for their own personal ambitions for power. 196

On August 27, two of Dellepiane's aids infiltrated a large meeting of military conspirators, bringing back to him a list of 36 army officers who had atterided the meeting. The next day Dellepiane spoke with Irigoyen explaining the situation and presenting two demands: to give him authority to arrest all known military conspirators, and that Irigoyen dismiss the Interior Minister, Elpidio González, Finance Minister, Enrique Perez Colman, the Chief of Police, Juan Graneros, and others in the Cabinet as they were the main reason for public discontent that had led to the revolutionary activities. Dellepiane told Irigoyen that he was surrounded by traitors. Irigoyen reluctantly acceded to these demands. 197 Without delay, Dellepiane swung into action to neutralize the oncoming revolt. 
González and Graneros, who had entered the presidential office toward the end of Dellepiane's interview, convinced Irigoyen that Dellepiane was mistaken and that the operation should be cancelled as it would incense the public. Acting upon their advice, Irigoyen told Dellepiane not to detain anyone without his approval and that the second demand would not be met. 198 Hearing this, Dellepiane said, "It is well. Now we will all sink and it's the President's fault." 199 The War Minister, feeling that his usefulness in Irigoyen's cabinet had ceased, resigned on September 3, 1930. In his letter of resignation he stated:

I am not political, but I am repulsed by what I see around me. Incapable and ambitious people do fundamental work. I see the people around you (Irigoyen) are interested in themselves and few are loyal. There should be an investigation of many people.... I only regret that I could not help you out of the present crisis....200

As Dellepiane was the only Minister well informed about the military conspiracy and the only one willing to do anything effective against it, with his resignation the government came to a rapid end. Dellepiane's successor, Elpidio González, a Cabinet conspirator, did not attempt to halt the military uprising. 201

The Liga Patriótica and Liga Republicana provoked increasing turmoil during the last days of August until the revolt. Reaction against Irigoyen was further evidenced at the formal opening of the annual Palermo cattle show of the Argentine Rural Society on August 3!, 1930. The Minister of Agriculture was shouted out of the hall without delivering his scheduled speech. 202

On September 1, the university students in Buenos Aires joined in demonstrating against the government. They issued a manifesto which denounced the governmental crisis, and threatened to take to the streets in protest if the unconstitutional measures 
adopted by Irigoyen and the administrative corruption were not corrected immediately. 203

The decisive event, which convinced the military conspirators that the revolution was al ready in the streets and it was time to act, occurred early in the evening of September 4 . The university students had organized a demonstration, several thousand strong, which vociferously asked for Irigoyen's resignation. They violently confronted the police; the result was one dead and several wounded. 204

This convinced the Cabinet conspirators that they should ask Irigoyen to delegate his presidential authority to the Vice President. On the afternoon of September 5, Cabinet Ministers González, Oyhanarte and de la Campa went to Irigoyen's residence on Brazil Street. González spoke for the group. Irigoyen, upon hearing his purpose, dismissed him sharply. Only the intervention of Irigoyen's personal physician finally convinced the President (who had been running a high fever for the past several days) 205 to delegate his authority to the Vice President, Enrique Martínez. 206

The new acting-President immediately decreed a state of siege for thirty days in Buenos Aires to control street demonstrations and to impede the expected military uprising. 207 In order to restore confidence in the government, Martínez ordered a Cabinet shakeup. The Ministers of Foreign Relations, Interior, Agriculture and Navy were dismissed and new appointments made. But the Foreign Minister, Oyhanarte, denied Martinez the authority to effect these changes. But it was to no avail. 208 
General Uriburu, after gaining the support of the Justo faction in the Army, gave orders to start the military uprising early on the morning of September 6, 1930. 


\section{FOOTNOTES FOR CHAPTER II}

'Felix Luna, Yrigoyen (Buenos Aires: Editorial Desarrollo, 1963), pp. 1-42, and Galvez, pp. $\overline{-56}$ cover this period of Irogoyen's life.

2 Herminio Muchnik (ed.), Presidentes Argentinos: Quiénes fueron, cuándo gobernaron, cómo eran y cómo vivieron. (Buenos Aires: Compañía General Fabril Editora, 1961) p. 169.

3Friedrich Heer, The Intellectual History of Europe, Vol. II. The CounterReformation to 1945, trans. Jonathan Steinberg. (New York: Doubleday \& Company, Inc., 1968), p. 252, calls Krause a third-rate philosopher. Because he is so obscure there is very little material written on him in English.

4White, p. 130.

${ }^{5}$ Galvez, p. 62.

6Galvez, p. 64.

7 White, p. 130.

8 White, p. 131.

${ }^{9}$ Galvez, p. 63.

10White, p. 131.

11 Galvez, p. 65, and White, p. 131.

12White, p. 131.

13 Luna, p. 45.

14 New York Times, October 21, 1928. 
15D.S.F., 835.00/436, Bliss to the Secretary of State, July 31, 1929.

16D.S.F., 835.00/442, Bliss to the Secretary of State, October 30, 1929.

17Diez periodistas porteños, Al Margen de la conspiración. (Buenos Aires: Biblos Editorial n.d.), p. 59.

18D.S.F., 835.55/72, Embassy BA dispatch, February 23, 1929.

19D.S.F., 835.55/73, Embassy BA dispatch, July 26, 1929.

20D.S.F., 835.55/72, Embassy BA dispatch, February 23, 1929.

${ }^{21}$ Diez periodistas, p. 110.

${ }^{22}$ Goldstrai, p. 35.

23D.S.F., 835.00/425, Bliss to the Secretary of State, May 14, 1929.

${ }^{24}$ D.S.F., 835.00/436, Bliss to the Secretary of State, July 31, 1929.

25D.S.F., 835.00/436, Bliss to the Secretary of State, July 31, 1929.

26 Macdonald, p. 197.

27Felix J. Weil, Argentine Riddle (New York: The John Day Company, 1944), p. 37.

28D.S.F., 835.032/84, Embassy BA dispatch, June 10, 1929.

29Macdona!d, pp. 203-204.

30 Macdonald, pp. 144-45.

31D.S.F., 835.032/69, Embassy BA dispatch, Apri! 7, 1926.

${ }^{32}$ This is based on the accounting law of 1885, Law 1606, Macdonald, p. 316. 33Macdonald, p. 198. 
34Diez periodistas, p. 10, and Macdonald, p. 226.

35Diez periodistas, pp. 10-11.

36D.S.F., 835.00/436, Bliss to Secretary of State, July 31, 1929.

37D.S.F., 835.00/404, Bliss to the Secretary of State, October 5, 1928.

${ }^{38}$ Chapter III, Article 86, 10th gives the President the power to choose and dismiss cabinet ministers without Senate approval.

39S. Viale Ledesma, 6 de septiembre el pueblo, el ejército y la revolución. (Buenos Aires: Ediciones Mercurio, n.d.), p. 12.

${ }^{40}$ D.S.F., 835.00/436, Bliss to the Secretary of State, July 31, 1929.

${ }^{41}$ José Nicolas Matienzo, La Revolución de 1930 y los problemas de la democracia Argentina (Buenos Aires: Librería Anaconda, 1930), p. 31.

42D.S.F., 835.00/444, Bliss to the Secretary of State, November 12, 1929.

43D.S.F., 835.00/436, Bliss to the Secretary of State, July 31, 1929.

44 Vernon L. Phelps, The International Economic Position of Argentina (Philadelphia: University of Pennsylvania Press, 1933), pp. 44, 49, and 55.

45 Ricardo M. Ortiz, "El aspecto económico-social de la crisis de 1930," Revista de historia, No. 3, 1958, p. 69.

${ }^{46}$ Harold Edwin Peters, "The Foreign Debt of the Argentine Republic" (unpublished Ph.D. dissertation: Johns Hopkins University, 1934), p. 102.

47Peters, p. 64.

48 peters, p. 126.

49Phelps, p. 52.

50 Phelps, p. 54. 
${ }^{51}$ D.S.F., 835.451, Embassy BA dispatch, December 16, 1929.

52D.S.F., 835.51/625, Embassy BA dispatch, December 23, 1929, reported that the closing of the caja hurt importers and incensed the foreign business community.

53 Peters, p. 178.

54 Peters, p. 175.

${ }^{55}$ La Prensa, August 15, 1930.

56 Peters, p. 57.

57Peters, p. 155.

58 Peters, p. 155.

${ }^{59}$ Peters, p. 136.

60Peters, p. 107.

${ }^{61}$ New York Times, November 4, 1928.

62D.S.F., 835.51/613, Bliss to the Secretary of State, March 20, 1929.

${ }^{63}$ D.S.F., 835.00/437, Bliss to the Secretary of State, September 4, 1929.

${ }^{64}$ New York Times, July 18, 1929.

65D.S.F., 835.00 Ir 4/20, Embassy BA dispatch, March 20, 1929.

${ }^{66}$ Carlos R. Porto, et al., Irigoyen proceso a su gobierno, los diplomas de San Juan, la oposición, cesantía, unicato (Bueros Aires: Editor Atilo Moro, 1929), p. 128 .

67D.S.F., 835.00/437, Bliss to the Secretary of State, September 4, 1929.

68D.S.F., 835.00/436, Bliss to the Secretary of State, July 31, 1929.

69D.S.F., 835.00/442, Bliss to the Secretary of State, October 30, 1929. 
70 New York Times, September 15, 1930.

${ }^{71}$ New York Times, December 2, 1928.

72La Prensa, January 6, 1929.

73 Mantienzo, p. 51.

74 Mantienzo, p. 57.

75Diez periodistas, pp. 11-12.

76Gobierno Provisional, La obra de la revolución: reseña de la labor desarrollada 6 de septiembre 1930-1931 (Buenos Aires: n.p., 1931), p. 59.

77New York Times, August 29, 1930.

${ }^{78}$ New York Times, August 29, 1930.

${ }^{79}$ La Prensa, August 15, 1930.

${ }^{80}$ La Prensa, August 29, 1930.

${ }^{81}$ Santander, p. 109.

${ }^{82}$ La Prensa, August 12, 1930.

83 La Prensa editorial, September 30, 1929.

84New York Times, April 1, 1930.

${ }^{85}$ New York Times, April 1, 1930.

${ }^{86}$ New York Times, April 1, 1930.

87 La Prensa editorial, August 9, 1930.

88 Modestino A. Pizarro, La verdad sobre la intervención en San Juan: 23 de diciembre de 1928, 6 de septiembre de 1930 (Buenos Aires: Talleres Gráficos Argentinos, J. L. Rosso, 1930), p. 85. 
${ }^{89}$ Escobar, p. 535.

90Federico Pinedo, En tiempos de la república. Vols. I-V. (Buenos Aires: Editorial Mundo Forense, 1946), Vol. II, pp. 284-85.

91 Pinedo, Vol. I, p. 70.

92pizarro, p. 42.

93pizarro, p. 11.

94 pizarro, p. 13.

95pizarro, p. 14.

96 pizarro, p. 17.

97pizarro, p. 16.

98 Pizarro, p. 71.

${ }^{99}$ Pinedo, Vol. I, p. 71.

100 La Prensa, January 25, 1929.

10! La Nación (Buenos Aires), January 24, 1929, as stated in Davenport, p. 110.

102 Hipólito Yrigoyen, Pueblo y gobierno, Vols. $1-X \mid 1$ (2d ed. Buenos Aires: Editorial Raigal, 1956), Vol. VI, pp. 509-18.

103Yrigoyen, Pueblo y gobierno, Vol. VI, p. 514.

104Yrigoyen, Pueblo y gobierno, Vol. VI, pp. 514-16.

105 La Prensa editorial, A.pril 26, 1929.

${ }^{106}$ La Prensa, August 12, 1929.

107 Porto, p. 189. 
108 Nicolas Repetto, Mi paso por la política: De Roca a Yrigoyen (Buenos Aires: Santiago Rueda, 1956), p. 316.

${ }^{109}$ La Prensa, August 23, 1929.

${ }^{110}$ Gomez, p. 56 .

$111_{\text {Pizarro, p. } 11 .}$

112 Porto, p. 384.

113 Escobar, p. 536 .

${ }^{114}$ La Prensa, August 13, 1929.

115D.S.F., 835.00/445, Bliss to the Secretary of State, November 13, 1929.

116 D.S.F., 835.00/445, Bliss to the Secretary of State, November 13, 1929.

117 La Prensa, November 11, 1929.

$118_{\text {Repetto, p. } 295 .}$

${ }^{119}$ La Prensa, November 13, 1929.

120 La Prensa, November 24, 1929.

121 La Prensa, November 25, 1929.

122 La Prensa, November 26, 1929.

123 Ibarguren, p. 372.

124Repetto, pp. 300-301.

125pinedo, Vol. II, p. 447.

${ }^{126}$ La Prensa, August 8, 1930.

127 Ledesma, p. 29. 
128

La Prensa, August 3, 1930.

129 Pinedo, Vol. II, p. 469.

$130_{\text {Repetto, p. } 318 .}$

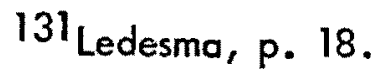

132 La Prensa editorial, August 8, 1930.

133 Pinedo, Vol. II, pp. 441-43.

${ }^{134}$ Alfredo Colomo, La revolución en la America Latina 2d ed. (Buenos Aires: M. Gleizer, Editor, 1933), p. 52 .

135 La Prensa, August 13, 1930.

${ }^{136}$ La Prensa, August 14, 1930.

137 La Prensa, August 17, 1930.

${ }^{138}$ La Prensa, August 20, 1930.

${ }^{139}$ La Mañana (Buenos Aires), August 20, 1930, as quoted in Davenport, p. 131. 140 Gomez, p. 65.

${ }^{141}$ D.S.F., 835.032/85, Bliss to the Secretary of State, August 21, 1929.

142Etchepareborda, Historia, p. 355.

${ }^{143}$ D.S.F., 835.032/183, Bliss to the Secretary of State, May 15, 1929.

144D.S.F., 835.032/84, Embassy BA dispatch, June 10, 1929.

145 Yrigoyen, Pueblo y Gobierno, Vol. IV, p. 77.

146Yrigoyen, Pueblo y Gobierno, Vol. IV, pp. 77-78.

147D.S.F., 835.032/87, Bliss to the Secretary of State, November 15, 1929. 
148 Etchepareborda, Historia, p. 361.

149 José Landa, Hipólito Yrigoyen visto por uno de sus médicos: estudio caracterológico de su personalidad (Buenos Aires: n.p., 1958), p. 430.

150 La Nación, September 9, 1929, as quoted in Davenport, p. 59.

$151_{\text {Repetto, pp. 316-18. }}$

152Goldstrai, p. 74.

153Ledesma, pp. 14-15.

${ }^{154}$ Gobierno Provisional, p. 16 and Repetto, p. 328.

155/baraguren, p. 375 .

156 La Prensa, August 1, 1930.

157 La Prensa, August 6, 1930.

${ }^{158}$ La Prensa editorials, August 1-August 30.

${ }^{159}$ Etchepareborda, Historia, p. 357.

160Robert A. Potash, The Army \& Politics in Argentina 1928-1945: Yrigoyen to Perón (Stanford: Stanford University Press, 1969), p. 30.

${ }^{161}$ La Prensa, August 5, 1930.

162 Potash, p. 35.

${ }^{163}$ Galvez, p. 411 and Potash, p. 36.

164 Potash, p. 36.

165D.S.F., 835.00/442, Bliss to the Secretary of State, October 30, 1929.

166 Potash, pp. 33-34. 
167Potash, pp. 31-32.

168 Potash, p. 51.

169 Juan V. Orona, "Una logia poco conocida y la revolución del 6 de septiembre," Revista de historia, No. 3, 1958, p. 74.

170 Potash, p. 38.

171D.S.F., 835.00/439, Bliss to the Secretary of State, October 11, 1929.

172Etchepareborda, "Aspectos," p. 17.

173 Luna, pp. 341-358.

174pinedo, Vol. I, p. 69.

175Romero, p. 118.

176 Luna, p. 347.

177/barguren, p. 372.

178 Goldstrai, p. 85 .

179 Luna, p. 345.

180 Goldstraj, p. 85 and Luna, p. 336.

$181_{\text {Luna, p. } 354 .}$

182La Prensa editorial, August 3, 1930.

183Coronel J. Bersford Crawks, 533 dias de la historia de la Argentina: 6 de septiembre de 1930, 20 de febrero de 1932 (Buenos Aires: Imprenta Mercatali, 1932), pp. 16-18.

184Del Mazo, Notas, p. 150.

185Bersford Crawks, p. 19. 
186 Del Mazo, Natas, p. 153.

187Potash, p. 43.

${ }^{188}$ Ibarguren, pp. 384-85.

189 José Maria Sarobe, Memorias sobre la revolución del 6 de septiembre de 1930 (Buenos Aires: Ediciones Gure S.R.L., 1957), p. 21.

190 Landa, p. 452.

191 José Ferrer, "The Armed Forces in Argentine Politics to 1930" (Unpublished Ph.D. dissertation, University of New Mexico, 1965), p. 207.

192Etchepareborda, Historia, p. 368.

193 Sarobe, p. 84.

194Etchepareborda, Historia, pp. 372-75.

195Luna, pp. 362-63.

196Ferrer, p. 201.

197Sarobe, pp. 88-90.

${ }^{198}$ Sarobe, p. 91.

${ }^{199}$ Sarobe, p. 92.

200La Prensa, September 3, 1930.

${ }^{201}$ Bersford Crawks, p. 35.

${ }^{202}$ Alfred Hasbrouck, "The Argentine Revolution of 1930," Hispanic American Historical Review, XVIII, August 1938, p. 29.

${ }^{203}$ Alfredo L. Palacios, En defensa de las instituciones libres (Santiago de Chile: Ediciones Ercilla, i936), p. 16. 
${ }^{204}$ Diez Periodistas, pp. 122-130.

205Santander, p. 83.

206 Diez Periodistas, pp. 131-35.

207 Bersford Crawks, p. 90.

${ }^{208}$ Etchepareborda, Historia, pp. 373-74. 


\section{CHAPTER III}

\section{CONCLUSION}

The causes of the revolution go beyond the events of 1928 to September 6, 1930. The authors of the 1853 Constitution wanted to establish a democracy. But they left the power in the hands of the dominant economic interests of the nation. As immigration increased so did the midcle sectors' demand for a voice in the government. But the oligarchy, which firmly controlled the government, kept them out. Their protests were in vain. They could not achieve any modifications in the government through legal channels. The only path open was revolution. The abortive revolts of 1890, 1893, and 1905 followed.

Eventually the oligarchy realized that if the middle sectors achieved power through a revolution, then their own power could easily be destroyed, along with their financial base. So overtures were made to bring the opposition into the government.

It was all based on expediency. Since the oligarchy did not want to be destroyed they had to share their power. This expediency did not create a democratic system any more than the Constitution of 1853 had. When the Sáenz Peña electoral reforms provided the basis for free elections, opposition faced opposition. There were no parties or platforms. The struggle was for plain 
unadulterated power. Nothing in the political arena had been institutionalized. The conservatives were completely fragmentized with independent parties in each of the provinces. The opposition was little better with numerous parties scattered throughout the nation.

In this chaotic situation Hipólito Irigoyen had an advantage, as he was the only presidential candidate in 1916 who had any type of an effective national organization. But what was more important, Irigoyen embodied the sentiments of the middle sectors. The people believed that he could fulfill their hope of a decent and honorable life. The people voted for Irigoyen for this reason alone. His popularity was completely based on his personal integrity and ideals, not on a program or plan for uplifting the people, as he had none. Because of this, his backing was personal, and it remained that way. The loyalty was to the man, not to the vague proposals that he cloaked in his Krausian philosophy.

This was a serious deficiency in the democratic process. Men, not issues, were important and Hipolito Irigoyen was the man. The government revolved around him in 1916 and 1928 . This is why, after he had accomplished so little during his first term, his popularity increased through Alvear's term, as no one could embody the public spirit as Irigoyen had. The people loved him--to a point.

But there were other deficiencies, notably in the executive's dominance over the rest of the government. The President was responsible for most of the governmental activities, and without his approval everything stopped. As long 
as the executive was able to keep the government functioning on a smooth basis there were no problems. This had been the case up to 1928. But when Irigoyen arbitrarily insisted upon the scrutinization of every voucher that was to pass under his nose, he quickly disrupted the governmental process. Payments were held up, contracts were not let, people were dismissed and not replaced. The government became disjointed, not from the world depression, but from Irigoyen's policies.

Irigoyen completely dominated his subordinates while directing the administration's policies. He held all of the power. The cabinet ministers could only act with his approval; as such their function was to advise and obey. For Irigoyen to be competent he had to be well informed of the issues and public attitudes. He was not. His intimate advisors lied to him, conspired against him, and isolated him from the public. This made the executive's dominance over the rest of the government a complete liability.

To further his dominance, Irigoyen intervened in the provinces where the opposition parties held power. There were valid reasons for each of the interventions, but in San Juan and Mendoza the interventors ruthlessly tried to obliterate the opposition. The obvious abrogation of the electoral laws caused public revulsion throughout the nation. These methods used in the suppression of the cantonistas and the lencinistas were viewed as much worse than the injustices perpetr ated by these regimes.

The opposition saw two things: the government was not functioning properly and their right to dissent was being challenged. By mid-1930 it appeared that 
Irigoyen's desire to further obliterate the opposition was spreading. Congress was paralyzed because of its opposition to Irigoyen. And in August came the news of the proposed Entre Rios intervention. How much further would Irigoyen's usurpation of power go?

If Irigoyen's desire to direct every detail of the national government had been backed by a purposeful program and had been executed in a methodical efficient pattern, he would have been able to maintain popular support, even in the light of his disregard of the Constitution and other laws. But he had no plan. The only apparent goal was power, and he incompetently misused his power to bring the nation to its knees, not the opposition.

The situation was unique. Irigoyen was destroying the opposition by the illegal and immoral methods that he had fought against for thirty years, but he did not use the power that he had usurped. It lay idle. His operating on the margin of legality could have generated support from the middle sectors, if he had enacted some pervasive social measures; instead he only offered them token panaceas. He lost the support of the people. This loss of support, due to lack of energy, coupled with his maintaining power through illegal methods, provoked the revolution. Irigoyen effectively destroyed the fev democratic traditions and free institutions that he had wanted so much to establish, by giving birth to the succeeding military governments. 


\section{BIBLIOGRAPHY}

Abalos, Jose Benjamín. "Testimonio," Revista de historia, No. 3, 1958, pp. 95-98.

Albrieu, Oscar E., et al. Tres revoluciones (los últimos veintiocho años). Buenos Aires: Editor Emilio Perrot, 1959.

Alen Lascano, Luis C. Hispano-América en el pensamiento de Yrigoyen. Buenos Aires: Editorial Propulsión (Ediciones Cívicas Argentinas), 1959.

Amuchastegui, Dr. Nicolas R. Anuncios y factores de un derrumbe: Apreciacones político-sociales 1929-1930. Rosario: R. T. Suarez, 1931.

Antille, Armando G., Proceso y defensa de Hipslito Irigoyen. Santa Fe, Argentina: Libreria y Editoria Castellvi S.A., 1946.

Barager, Joseph R. Why Perón Came to Power. New York: Alfred A. Knopf, 1968.

Beresford Crawks, Coronel J. 533 dias de la historia Argentina: 6 de septiembre de 1930, 20 de febrero de 1932. Buenos Aires: Imprenta Mercatali, 1932.

Bosch, Mauiano G., Historia del Partido Radical: La U.C.R. 1891-1930. Buenos Aires: Edición Del Autor, 193T.

Cacavelos, Juan M. and Julio Artayeta. Hipólito Yrigoyen: paladín de la democracia. Buenos Aires: Editorial Argentina "Santa Teresita," 1939.

Carrasco, Angel. Lo que yo vi desde el 80: Hombres y episodios de la transformación nacional. Buenos Aires: Editorial P.R.O.C.M.O., 1947.

Carulla, Juan E. "Entretelones de la revolución de 1930," Revista de historia, No. 3, 1958, pp. 119-122.

Colomo, Alfredo. La revolución en la America Latina. 2d. ed. Buenos Aires: M. Gleizer, Editor, 1933.

Cugini, Roberto. Yrigoyen y el silencio. Buenos Aires: Talleres Gráficos Argentinos, L. J. Rosso, 1928. 
Davenport, Robert Wilson. "The Revolution of 1930 in Argentina." Unpublished Master's Thesis, History Department, University of California at Berkeley, 1953.

Del Mazo, Gabriel. El pensamiento escrito de Yrigoyen. 2d ed. Buenos Aires: Edición Argentina, 1945.

Del Mazo, Gabriel. El Radicalismo: Notas sobre su historia y doctrina. Buenos Aires: Editorial Raigal, 1955.

Del Mazo, Gabriel. Yrigoyen vivo. Buenos Aires: Editorial Raigal, 1952.

Diaz, Alfonso. El Presidente Yrigoyen y su misión histórica. Buenos Aires: Editorial Tor, 1929.

Diez periodistas porteños. Al margen de la conspiración. Buenos Aires: Biblos Editorial, n.d.

Dominguez, Emilio. El 6 de septiembre de 1930. Buenos Aires: Agencia General de Libreria y Publicaciones (Talleres Grafficos Argentinos, L. J. Rosso), M.d.

Escobar, Ismael Bucich. Historia de los presidentes Argentinos. Buenos Aires: Roldan, 1934.

Etchepareborda, Roberto. "Aspectos políticos de la crisis de 1930." Revista de historia. No. 3, 1958, pp. 7-40.

Ferns, H. S. Argentina. New York: Frederick A. Praeger, 1969.

Ferrer, Aldo. The Argentine Economy. Translated by Marjory M. Urquidi . Berkeley and Los Angeles: University of California Press, 1967.

Ferrer, José. "The Armed Forces in Argentine Politics to 1930." Unpublished Ph.D. dissertation, University of New Mexico, 1965.

Fitzgibbon, Russel H. (ed.). The Constitutions of the Americas (as of January 1, 1948). Chicago: The University of Chicago Press, 1948.

Frondizi, Arturo. Petroleo y política: Contribución al estudio de la historia económica argentina y de Tas relaciones entre el imperialismo y de la vida política nacional. Buenos Aires: Editorial Raigal, 1955.

Galindez, Bartolome. Apuntes de tres revoluciones (1930-1943-1955). Buenos Aires: Talleres gráficos de Castro Barrera y Cia., 1956.

Galvez, Manuel. Vida de Hipolito Yrigoyen: el hombre del misterio. 2d ed. Buenos Aires: Ediciones Anaconda, 1939. 
Galzarza, Ernest. "Argentina's Revolution and Its Aftermath." Foreign Policy Reports. Vol. 7 (17), 1931, pp. 309-22.

Giuffra, Eduardo F. Hipólito Yrigoyen en la historia de las instituciones Argentinas. Buenos Aires: Editorial de la Fundacion, 1969.

Gobierno Provisional. La obra de la revolución: resena de la labor desarrollada 6 de septiembre 1930-1931. Buenos Aires: n.p., 1931.

Goldstraj, Manuel. Anos y errores (un cuarto de siglo de política Argentina). Buenos Aires: Editorial Sophos, 1957.

Gomez, Rosendo A. "Intervention in Argentina, 1860-1930." Inter-American Economic Affairs. 1:3 December 1947, pp. 55-73.

Guitierrez de Miguel, V. La revolución Argentina: relato de un testigo presencial. Madrid: Compañía lbero Americana de Publicaciones, S.A., 1930.

Hasbrouck, Alfred. "The Argentine Revolution of 1930." Hispanic American Historical Review, XVIII, August 1938, pp. 285-381.

Heer, Friedrich. The Intellectual History of Europe. Volume II. The CounterReformation to 1945. Translated by Jonathan Steinberg. New York:

Doubleday \& Company, Inc., 1968.

Ibarguren, Carlos. La historia que he vivido. Buenos Aires: Fdiciones Peuser, 1955.

Landa, José. Hipólito Yrigoyen visto por uno de sus médicos: estudio caracterológico de su personalidad. Buenos Aires: n.p., 1958.

Ledesma S. Viale. 6 de septiembre el pueblo, el ejército y la revolución. Buenos Aires: Edictiones Mercurio, n.d.

López, Vincente Fidel, Emilio Vera y Gonzalez and Enrique de Gandia. Historia de la república Argentina. Vol. VIII, 7th ed. Buenos Aires: Editorial Sopena Argentina, S.A., 1964.

Lugones, Leopoldo. Los Argentinos y su historia interna. Buenos Aires: Ediciones Centurion, 1962.

Luna, Felix. Yrigoyen. Buenos Aires: Editorial Desarrollo, 1963.

Macdonald, Austin F. Government of the Argentine Republic. New York:

Thomas Y. Crowell Company, 1942. 
Marianetti, Benito. Argentina: Realidad y perspectivas. Buenos Aires: Editorial Plantina, 1964.

Matienzo, Jose Nicolas. La revolución de 1930 y los problemas de la democracía Argentina. Buenos Aires: Libreria Anaconda, 1930.

Menendez, Armando Braun, et al. Historia Argentina contemporanea 1862-1930. Buenos Aires: El Ateneo, $\overline{19} 64$.

Merchensky, Marcos. Las corrientes ideologicas en la historia Argentina. Buenos Aires: Editorial Concordia, 1961.

Muchnik, Herminio (ed.). Presidentes Argentinos: Quiénes fueron, cuándo gobernaron, cómo eran y cómo vivieron. Buenos Aires: Compañía General Fabril Editora, 1961.

New York Times, 1928-1930.

North, Liisa. Civil-Military Relations in Argentina, Chile, and Peru. Berkeley: (By the regents of the University of Californic) Institute of International Studies, 1966.

Orona, Juan V. La logia militar que enfrontó a Hipólito Yrigoyer. Buenos Aires: Copyright by Juan V. Orona 1965.

Orona, Juan V. La revolución del 6 de septiembre. Buenos Aires: Copyright by Juan V. Orona, 1966.

Orona, Juan $V$. "Una logia poco conocida y la revolución del 6 de septiembre." Revista de historia, No. 3, 1958, pp. 73-94.

Ortega, Exequiel. Quiera el pueblo votar?: Historia electoral Argentina, desde la Revolución de Mayo, a la Ley Sáenz Peña, 1810-1912. Bahía Blanca: V. M. Giner, 1963.

Ortiz, Ricardo M. "El aspecto económico-social de la crisis de 1930." Revista de historia, No. 3, 1958, pp. 41-73.

Oyhanarte, Horacio B. El hombre Hipólito Irigoyen apostol de la democracía. 20th ed. Editorial Claridad, Buenos Aires, 1945.

Oyhanarte, Raul F. Radicalismo de siempre. 2d ed. La Plata: Editado por El Club Radical de Hombres Libres, 1932. 
Palacios, Alfredo L. En defensa de las instituciones libres. Santiago de Chile: Ediciones Ercilla, 1936.

Parker, William Belmont (ed.). Argentines of To-Day. Vols. I and II. New York: Kraus Reprint Corporation, 1967. (First published in 1920. New York: Hispanic Society of America.)

Perón, Juan. Tres revoluciones militares. Buenos Aires: Escorpion Ediciones, 1963.

Peters, Harold Edwin. "The Foreign Debt of the Argentine Republic." Unpublished Ph.D. dissertation. Johns Hopkins University, 1934.

Phelps, Vernon L. The International Economic Position of Argentina. Philadelphia: University of Pennsylvania Press, 1938.

Pinedo, Federico. En tiempos de la república. Vols. I-V. Buenos Aires: Editorial Mundo Forense, 1946.

Pineiro, Armando Alonso. Vidas de grandes Argentinas. Vols. I-III. Buenos Aires: Ediciones Antonio Fossati, 1960.

Pizarro, Modestino A. La verdad sobre la intervención en San Juan: 23 de diciembre de 1928, 6 de septiembre de 1930. Buenos Aires: Talleres Gráficos Argentinos J. L. Rosso, 1930.

Porto, Carlos R. et al. Irigoyen proceso a su gobierno, los diplomas de San Juan, la oposición, cesantías, unicato. Buenos Aires: Editor Atilo Moro, 1929.

Potash, Robert A. The Army \& Politics in Argentina 1928-1945: Yrigoyen to Perón. Stanford: Stanford University Press, 1969.

La Prensa, 1928-1930.

Puiggros, Rodolfo. Historia de los partidos políticos Argentinos. Buenos Aires: Editorial Argumentos, 1965.

Quesada, Julio A. Origenes de la revolución del 6 de septiembre de 1930. Buenos Aires: Libreria Anaconda, 1930.

Rennie, Ysabel F. The Argentine Republic. New York: The Macmillan Company, 1945.

Repetto, Nicolas. Mi paso por la política: De Roca a Yrigoyen. Buenos Aires: Santiago Rueda, 1956. 
República Argentina, Gobierno provisional de la nación. Documentos inicales de la revolución. Buenos Aires: Imprenta de la Camara de Diputados, 1930.

República Argentina, Ministerio del Interior, Subsecretaria de Informaciones. Las fuerzas armadas restituyen el imperio de la soberania popular: las eleciones generales de 1946, Vols. I and II. Buenos Aires: Imprenta de la Camara de Diputados, 1946.

Rodriguez, Carlos J. Irigoyen su revolución política y social. Buenos Aires: "La Facultad," $19 \overline{43 .}$

Rodriguez Tarditi, Jose. Semblanza de tres lideres. Buenos Aires: Bases Editorial, 1960.

Romero, Luis Alberto et al. El Radicalismo. Buenos Aires: Carlos Perez, Editor, 1968.

Salera, Virgil. Exchange Control and the Argentine Market. New York: AMS Press, Inc., 1968.

Sanchez, Viamonte, Carlos. El ultimo caudillo. Buenos Aires: Editorial Denver, 1956.

Santander, Silvano. Yrigoyen. Buenos Aires: Editorial La Fragua S.R.L., 1965.

Sarobe, José Maria. Memorias sobre la revolución del 6 de septiembre de 1930. Buenos Aires: Ediciones Gure S.R.L., 1957.

Scabie, James R. Argentina: A City and a Nation. New York: The Oxford University Press, 1964.

Sommi, Luis V. Hipólito Irigoyen su vida y su epoca. Buenos Aires: Editorial Manteagudo, 1947.

Snow, Peter G. Argentine Radicalism: The History and Doctrine of the Radical Civic Union. Tlowa City: University of lowa Press, 1965.

Spilimbergo, Jorge Enea. Nationalismo, oligarquico y nationalismo revolucionario. Buenos Aires: Editorial Amerindia, 1958.

Tornquist, Ernesto \& Co., Ltd. The Economic Development of the Argentine Republic in the Last 50 Years. Buenos Aires. n.p., 1919.

Torres, Arturo. Elpidio González: biografia de una conducta. Buenos Aires: Editorial Raigal, 1951. 
Tristan, Lucia. Yrigoyen y la intransigencial Radical. Buenos Aires: Editorial Indoamerica, 1955.

Troncoso, Oscar A. Los nacionalistas Argentinos: Antecedentes y trayectoria. Buenos Aires: Editorial S.A.G.A., 1957.

U.S. Department of State Files, File 835, Records of the Department of State relating to the Internal Affairs of Argentina, 1910-1929.

Weil, Felix J. Argentine Riddle. New York: The John Day Company, 1944.

Whitaker, Arthur P. Argentina. Englewood Cliffs, New Jersey: Prentice-Hall, Inc., 1964.

White, John W. Argentina: The Life Story of a Nation. New York: The Viking Press, 1942.

Yrigoyen, Hipólito. Mi vida y mi doctrina. Buenos Aires: Editorial Raigal, 1957.

Yrigoyen, Hipólito. Pueblo y gobierno. 2d ed, Vols. I-XII. Buenos Aires: Editorial Raigal, 1956.

Yunque, Alvaro. Leandro N. Alem: El hombre de la multitud. Buenos Aires: Editorial Americana, 1953. 